Review

\title{
Tetrazolium Compounds: Synthesis and Applications in Medicine
}

\section{Cheng-Xi Wei ${ }^{1, \dagger}$, Ming Bian ${ }^{1, \dagger}$ and Guo-Hua Gong ${ }^{1,2, *}$}

1 Medicinal Chemistry and Pharmacology Institute, Inner Mongolia University for the Nationalities, Tongliao 028000, Inner Mongolia, China; E-Mails: weichengxi1224@163.com (C.-X.W.); xiaopang1224@126.com (M.B.)

2 Affiliated Hospital of Inner Mongolia University for Nationalities, Tongliao 028000, Inner Mongolia, China

$\dagger$ These authors contributed equally to this work.

* Author to whom correspondence should be addressed; E-Mail: gongguohua0211@163.com; Tel./Fax: +86-475-831-4245.

Academic Editor: Derek J. McPhee

Received: 9 December 2014 / Accepted: 4 March 2015 / Published: 27 March 2015

\begin{abstract}
Tetrazoles represent a class of five-membered heterocyclic compounds with polynitrogen electron-rich planar structural features. This special structure makes tetrazole derivatives useful drugs, explosives, and other functional materials with a wide range of applications in many fields of medicine, agriculture, material science, etc. Based on our research works on azoles and other references in recent years, this review covers reported work on the synthesis and biological activities of tetrazole derivatives.
\end{abstract}

Keywords: tetrazole; sythesis; antibacterial; anti-inflammatory; anticancer; anticonvulsant

\section{Introduction}

Tetrazole is a heterocyclic compound containing a carbon atom and four nitrogen atoms in a five-membered ring. Theoretically there are three precursor tetrazole isomers: i.e., $1 H$-tetrazole (1), $2 H$-tetrazolium (2) and $5 H$-tetrazole (3) (Figure 1). Substituted tetrazoles exist as a nearly 1:1 ratio of $1 H$ - and $2 H$-tautomeric forms. Previous studies had shown that the two positional isomers $\mathbf{1}$ and $\mathbf{2}$ may be differentiated on the nuclear magnetic resonance (NMR) timescale [1]. 


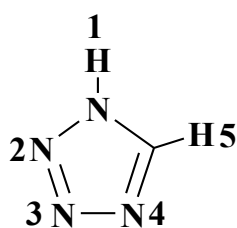

1

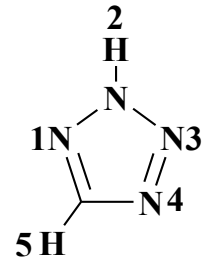

2

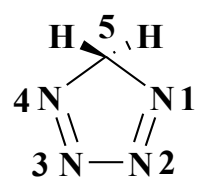

3

Figure 1. Structures of the regioisomeric tetrazole rings.

Like other azole compounds, due to the relatively late start of the synthesis and study of tetrazole compounds, they did not attracted much attention in the beginning. Since 1885, when Bladin first synthesized tetrazole derivatives (2-cyanophoric-5-phenyltetrazole) to 1950 , only some 300 kinds of derivatives were reported [2]. Since the 1950s, when tetrazole compounds became widely used in agriculture, biochemistry, medicine, pharmacology, explosives and other aspects, research began to develop rapidly $[3,4]$. The tetrazolyl functional group which was often considered as a carboxylic acid replacement in drugs, not only because the $\mathrm{pKa}$ is close, but it also has approximately the same planar delocalized system space requirements, and it provided a maximum nitrogen content of any heterocyclic compound [5]. The planar ring skeleton structure and the nitrogen-rich multi-electron conjugated system confer tetrazole derivatives with both donor and acceptor electronic properties. Tetrazole and its derivatives have this attracted the interest of scientists because of their unique structures and their potential applications as antihypertensive, anti-allergic, antibiotic and anticonvulsant agents [6-9]. In the present review, emphasis was focused on the diverse pharmacological properties associated with substituted tetrazoles in the past few years and a conclusive discussion on structure-activity relationship (SAR) of these compounds is provided.

\section{Preparation of Tetrazole Derivatives}

Several methods for the synthesis of tetrazoles are widely reported in the literature. The main synthetic routes to tetrazoles are outlined in Schemes 1-3. Tetrazoles could be synthesized by the reaction of substituted amines 4 with triethyl orthoformate and sodium azide in dimethyl sulfoxide (DMSO) [10,11] (Scheme 1). A new method to convert substituted amines into tetrazoles involves preparing functionalized superparamagnetic $\mathrm{Fe}_{3} \mathrm{O}_{4} \cdot \mathrm{SiO}_{2}$ possessing high saturation magnetization [12].

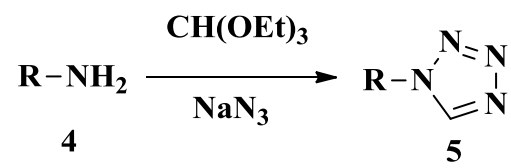

Scheme 1. Synthesized route 1 for tetrazoles.

The [3+2] cycloaddition between hydrazoic acid and cyanide derivatives is well known as an efficient route (Scheme 2). We can thus get substituted tetrazoles 5 from isocyanides $\mathbf{6}$. The reaction of 6 and azidotrimethylsilane (1.5 equiv.) was conducted in $\mathrm{MeOH}(0.5 \mathrm{M})$ in the presence of a catalytic amount of $\mathrm{HCl}\left(2 \mathrm{~mol} \%, 1.0 \mathrm{M}\right.$ in $\mathrm{Et}_{2} \mathrm{O}$ solution) at $60{ }^{\circ} \mathrm{C}[13,14]$. One of the main procedures frequently used for the preparation of 5-substituted tetrazoles 7 involves heating a suspension of $\mathbf{6}$, 
sodium azide, ammonium chloride and lithium chloride $(1.20 \mathrm{~g}, 28 \mathrm{mmol})$ in anhydrous dimethylformamide (DMF) under stirring at $110{ }^{\circ} \mathrm{C}$ [15-17]. Compound 7 was also obtained in a sealed pressure vessel reaction where $\mathrm{NaN}_{3}$ dissolved in $\mathrm{H}_{2} \mathrm{O}$, compound 6, ammonium chloride, ammonium fluoride and propane-1,2-diol (DPOL) were stirred and heated for $48 \mathrm{~h}$ [18]. Aryloxy tetrazoles were commonly prepared by the reaction of phenols with cyanogen bromide in the first step. Then sodium azide was added into refluxing acetone-water [19]. The most convenient route to 5 -substituted- $1 H$-tetrazoles 8 is the reaction of azide ion with nitriles [20]. The literature is full of examples of this conversion method. They can be divided into three main categories using tin or silicon azides [21], acidic media [22], and strong Lewis acids [23,24]. In addition, all of the known methods use organic solvents, in particular, dipolar aprotic solvents such as DMF [25]. A new method for the synthesis of 5-substituted-1H-tetrazoles method was reported where compound $\mathbf{6}$, water, sodium azide and zinc chloride were refluxed in a hood [26-28].

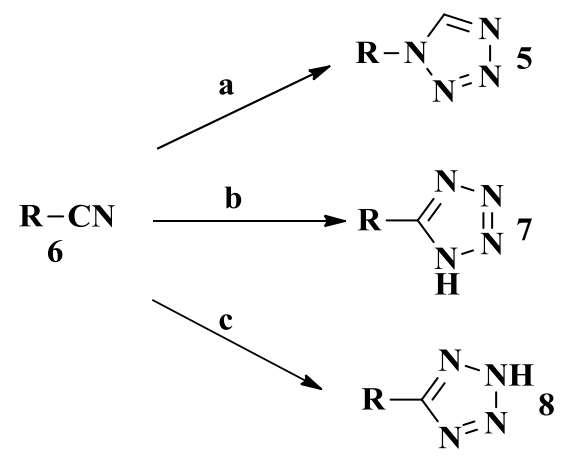

Reagents and Conditions: a: $\mathrm{MeOH}, \mathrm{HCl}, 6{ }^{\circ} \mathrm{C}$; b: (1) $\mathrm{NaN}_{3}, \mathrm{NH}_{4} \mathrm{Cl}, \mathrm{LiCl}, \mathrm{DMF}, 110{ }^{\circ} \mathrm{C}$; (2) $\mathrm{NaN}_{3}, \mathrm{NH}_{4} \mathrm{Cl}$, $\mathrm{NH}_{4} \mathrm{~F}$, DPOL, $48 \mathrm{~h}$; $\mathrm{c:} \mathrm{N}_{3}{ }^{-}, \mathrm{CN}^{-}$.

Scheme 2. Synthesized route 2 for tetrazoles.

If one wants to prepare 1,5-disubstituted-tetrazoles from the corresponding amide, there are many routes (Scheme 3). First, one can prepare an oxyphosphonium salt under Mitsunobu conditions from the corresponding amide, followed with reaction with trimethylsilyl azide leading to the desired 1,5-disubstituted-tetrazoles. This method proves to be especially useful for applications when an $\mathrm{N}$-protected tetrazole is required. Preservation of chirality in the synthesis of a tetrazole analogue of an amino acid (phenylalanine) was demonstrated [29]. In addition to the above direct approach, we can also through multiple steps to generate 1,5-disubstituted tetrazoles. Usually compounds 9 can be converted to compounds $\mathbf{1 0}$ with phosphorus oxychloride $\left(\mathrm{POCl}_{3}\right)$ and thionylchloride $\left(\mathrm{SOCl}_{2}\right)$ [30]. Compounds 11 can also be prepared in suitable yields by reaction of compounds 9 with Lawesson's reagent or phosphorus pentoxide [31]. 1,5-Disubstituted tetrazoles can also be synthesized by reacting compounds $\mathbf{1 0}$ with triethyl orthoformate and sodium azide [32]. Compounds $\mathbf{1 2}$ can be synthesized by the reaction of compounds $\mathbf{1 0}$ and compounds 11 with hydrazine hydrate [33,34]. 1,5-Disubstituted tetrazoles can finally be synthesized by reacting 12 with $\mathrm{CH}_{3} \mathrm{COOH}$ and aqueous $\mathrm{NaNO}_{2}$ under ice-bath conditions, making sure that the reaction temperature is below $5{ }^{\circ} \mathrm{C}[35,36]$. 


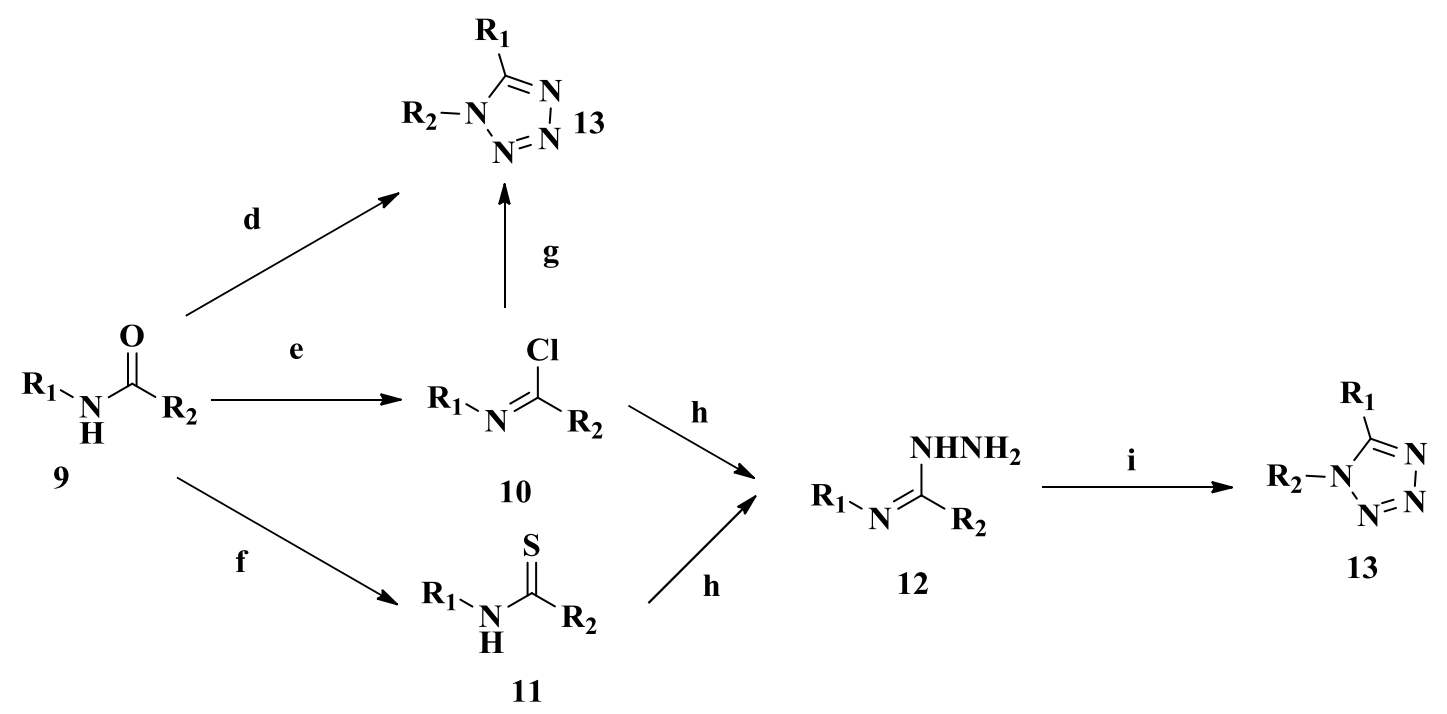

Reagents and Conditions: d: oxyphosphonium salt, $\mathrm{C}_{3} \mathrm{H}_{9} \mathrm{~N}_{3} \mathrm{Si}$; e: $\mathrm{POCl}_{3}, \mathrm{SOCl}_{2}$; f: Lawesson's reagent $/ \mathrm{P}_{2} \mathrm{O}_{5}$; g: $\mathrm{HC}\left(\mathrm{OC}_{2} \mathrm{H}_{5}\right)_{3}, \mathrm{NaN}_{3} ;$ h: $\mathrm{N}_{2} \mathrm{H}_{4} \cdot \mathrm{H}_{2} \mathrm{O} ;$ i: $\mathrm{CH}_{3} \mathrm{COOH}, \mathrm{NaNO}_{2}$, below $5{ }^{\circ} \mathrm{C}$.

Scheme 3. Synthesized route 3 for tetrazoles.

There are some ways to get 2,5-disubstituted-tetrazoles. One of the most efficient routes (Scheme 4) uses lithium trimethylsilyldiazomethane (15) prepared from $\mathrm{TMSCHN}_{2}$ and lithium diisopropylamide (LDA), which reacts smoothly with the methyl esters of carboxylic acids at $0{ }^{\circ} \mathrm{C}$ to give compounds $\mathbf{1 6}$ in good yields [37].<smiles>COC(C)=O</smiles>

Scheme 4. The most efficient route for synthesis of 2,5-disubstituted-tetrazoles.

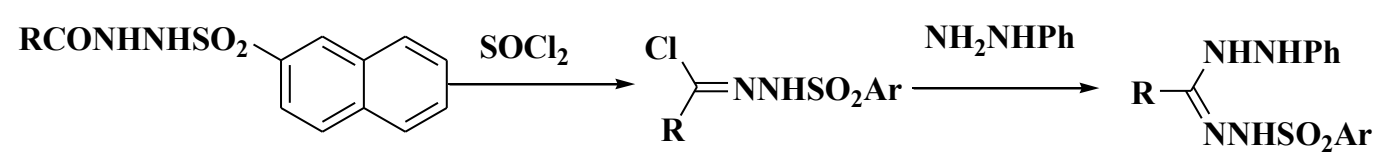

17

18

19

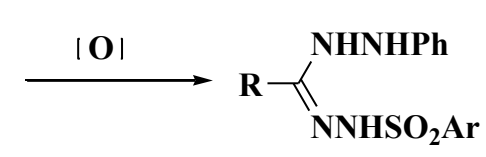

20

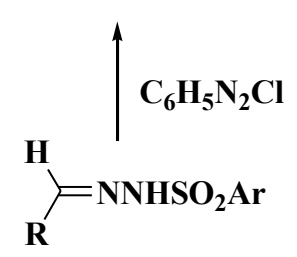

22

Scheme 5. Synthesized routes for compounds 18-22. 
When the hydrazides 17 were treated with thionyl chloride, the corresponding hydrazidoyl compounds 18 were obtained (Scheme 5). Next the reaction of compounds $\mathbf{1 8}$ with phenylhdyrazine was examined to prepare the hydrazidines 19 which can be oxidized to formazan derivatives $\mathbf{2 0}$. 2,5-Disubstituted tetrazoles $\mathbf{2 1}$ can be synthesized by reacting compounds $\mathbf{2 0}$ with potassium carbonate [38]. Compounds $\mathbf{2 0}$ also can be synthesized from compounds 22 [39].

\section{Biological Activity of Tetrazolium Derivatives}

Compounds derived from tetrazolium have received particular attention due to their pharmacological properties. Numerous studies have been published on the antibacterial and antifungal properties of these derivatives. Furthermore, these compounds also present anti-inflammatory, analgesic, anticancer, anticonvulsant, antihypertensive, hypoglycemic, antiparasitic, and antiviral activities. The aforementioned properties and the possibility to attach several structurally distinct substituents to the heterocycle ring to modify either the biological or physico-chemical properties of these compounds have prompted the use of this heterocycle as a template in many research programs aimed at the development of new bioactive compounds.

\subsection{Antibacterial and Antifungal Activity}

7,9-Disubstituted-7H-tetrazolo[1,5-c]pyrrolo[3,2-e]pyrimidines (Figure 2) were synthesized and evaluated for their antibacterial activity. Compound $\mathbf{2 3}$ exhibited better activity than ampicillin against all the tested cultures, except S. aureous [40]. A novel series of tetrazole compounds were reported to possess antimicrobial activity in vitro by the disc diffusion method measuring zones of inhibition. The results of the study showed that the synthesized compound 2-methyl-3-\{4-[2-(1H-tetrazol-5-ylethylamino]phenyl $\}$-3 $H$-quinazolin-4-one (24) displayed fairly good antimicrobial activity against the test organisms, although the activity was less than that of the reference drugs (ciprofloxacin and fluconazole, respectively) [41]. It was reported that a series of new 5-thio-substituted tetrazole derivatives were synthesized and antimicrobial screening showed that all the synthesized compounds showed moderate activity against the tested organisms. Among the newly synthesized compounds, 25 and 26 showed the most effective antibacterial and antifungal activities. The study suggested that further work with similar types of analogues was clearly warranted [42].

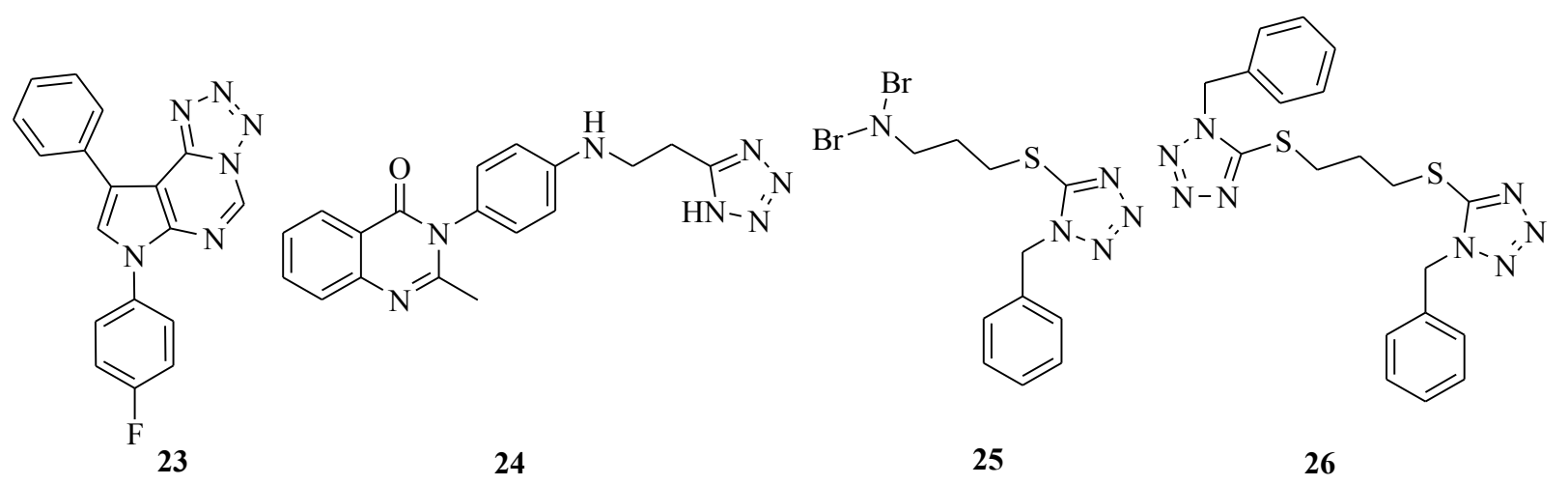

Figure 2. Structures of compounds 23-26. 
A variety of heterocyclic tetrazole derivatives were synthesized (Figure 3). Among the synthesized compounds, compounds 27, 28, 29, 30, 31 and 32 exhibited antimicrobial activities with minimal inhibitory concentration (MIC) values ranging from 23.40 to $46.87 \mu \mathrm{g} / \mathrm{L}$. Molecular modeling results were in accordance with the in vitro antimicrobial screening. The SAR research results showed that pyran derivatives were more active than pyridine derivatives and the activity order for the $\mathrm{R}$ substituent was: 4-OMe $>4-\mathrm{Me}>3-\mathrm{OH}>\mathrm{H}>4-\mathrm{Cl}>4-\mathrm{NO}_{2}[43]$.<smiles>COc1ccc(-c2cc(-c3ccc(Oc4nnnn4-c4ccccc4)cc3)c(C)c(OC)n2)cc1</smiles>

27<smiles>[R]c1cccc(C2=CC(c3ccc(Oc4nnnn4-c4ccccc4)cc3)C(C#N)=C(N)O2)c1</smiles>

$28 \mathrm{R}=4-\mathrm{OCH}_{3}$ $29 \mathrm{R}=4-\mathrm{CH}_{3}$<smiles>[R][X]c1ccc(C2=NN(C(C)=O)C(c3ccc(Oc4nnnn4-c4ccccc4)cc3)C2)cc1</smiles>

$30 \mathrm{R}=4-\mathrm{Cl}$

$31 \mathrm{R}=4-\mathrm{NO}_{2}$

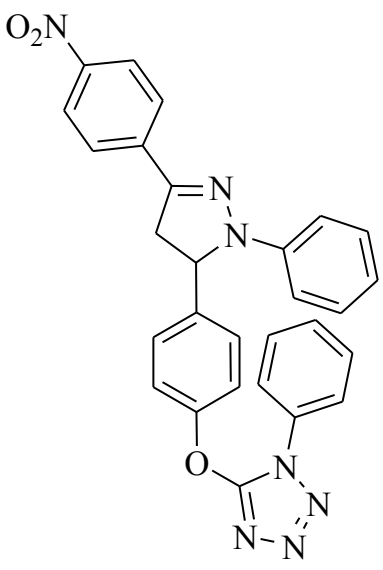

32

Figure 3. Structures of compounds 27-32.

A new series of oxazolidinone derivatives were synthesized (Figure 4) and evaluated their substituted effects on in vitro and in vivo antibacterial activities activity against clinically relevant resistant gram-positive organisms, $M$. catarrhlis and $H$. influenzae with a long half-life.

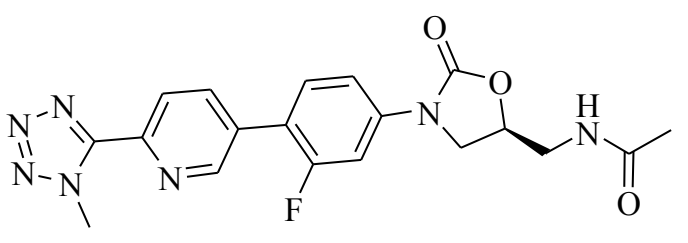

33<smiles>[R]c1ccc(C2c3c(c4ccccc4oc3=O)O[C@@H]3NC(=S)n4nnnc4C23)cc1</smiles>

$34 \mathbf{R}=4-\mathrm{Cl}$

$35 \mathrm{R}=4-\mathrm{OMe}$<smiles></smiles>

$36 \mathbf{R}=4-\mathrm{Cl}$

$37 \mathbf{R}=4-0 M e$

Figure 4. Structures of compounds 33-37.

Diverse substituted heteroaromatic ring forms were tolerated on the pyridine and the presence or orientation of the methyl group in the heteroaromatic ring affected the antibacterial activity. Among the new compounds, 33 was the most effective compound against a variety of clinically relevant resistant Gram-positive organisms and $M$. catarrhlis and $H$. influenzae, and also showed the higher in vivo efficacy with longer half-life than linezolid [44]. The synthesis of a series of novel 
pyranochromene-containing fused tetrazole derivatives was reported. All of the newly synthesized compounds were screened for their antibacterial activities against the Gram-positive bacteria Bacillus subtilis and Staphylococcus aureus and Gram-negative bacteria (Pseudomonas aeuroginosa and Escherichia coli). The antifungal activity of the compounds was assayed against Candia albicans and Aspergillus niger. The MIC values of the assayed compounds were determined using the microdilution susceptibility method. Ciprofloxacin was used as a reference antibacterial agent. Fluconazole was used as a reference antifungal agent. The study showed that compounds 34, 35, 36 and 37 showed significant antibacterial and antifungal activities compared with other tested samples [45].

The synthesis of new triazolo/tetrazolo-pyridazine[6,7]benzocycloheptenes (Figure 5) and their antimicrobial activity was reported. All the compounds were screened for the antibacterial activity in the appropriate concentration. The compound 2-methyl-6,7-dihydro-5H benzo[6,7]cyclohepta[1,2,3,4] tetrazolo[1,5-b] pyridazine (38) showed the maximum zone of inhibition (20 mm) against E.coli which was a little smaller than that of doxycyclin $(30 \mathrm{~mm})$ [46]. A series of tetrazole Schiff bases were prepared and it was demonstrated that these compounds possessed good antibacterial and antifungal activities when tested by the cup plate method. The most promising compounds with good antibacterial and antifungal activity were 39, 40 and $\mathbf{4 1}$, and the best ones for antifungal activity were 39, 40 and 42 [47].

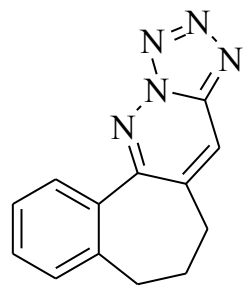

38

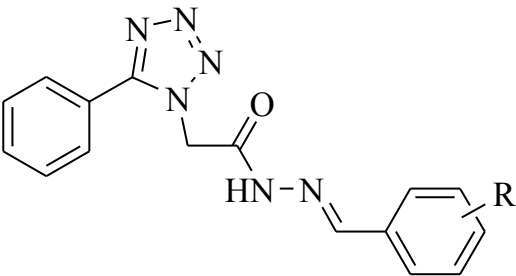

$39 \mathrm{R}=2-\mathrm{Cl}$

$40 \mathrm{R}=4-\mathrm{Cl}$

$41 \mathrm{R}=4-\mathrm{NO}_{2}$

$42 \mathrm{R}=4-\mathrm{CH}_{3}$

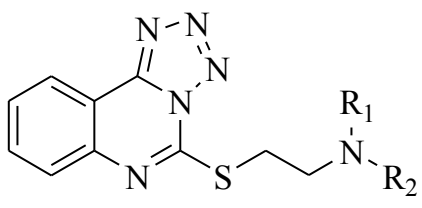

$43 \quad \mathbf{R}_{\mathbf{1}}=\mathbf{R}_{\mathbf{2}}=\mathbf{H}$

$44 R_{1}=R_{2}=M e$

$45 R_{1}=R_{2}=i$-Pr

Figure 5. Structures of compounds 38-45.

It was reported that a series of tetrazolo[1,5-c]quinazoline-5-thione derivatives (Figures 5 and 6) were synthesized and screened for antibacterial and antifungal activities at the concentration of $100 \mu \mathrm{g}$. The results revealed that the most active substances were $\mathbf{4 3}, \mathbf{4 4}, \mathbf{4 5}$, and $\mathbf{4 6}$. The SAR revealed that shortening of the dialkyl amino fragment of substances $\mathbf{4 3 - 4 5}$ leads to a moderate decrease in antimicrobial activity against Enterococcus faecalis, and otherwise leads to an increase in activity against Staphylococcus aureus and Escherichia coli, and antifungal activity against Candida albicans. Introduction of the 4-methoxyphenyl group at the 5 position of tetrazolo[1,5-c] quinazoline-5-thione (46) resulted in the best antimicrobial agent among all the investigated substances. It even moderately inhibited the growth of Pseudomonas aeruginosa and Klebsiella pneumoniae [48]. Other research results showed that $N$-(4-(2-(2H-tetrazol-5-yl)ethyl)-5-thioxo-4,5-dihydro-1,3,4-thiadiazol-2-yl)benzamide (47) exhibited antimicrobial activity against Bacillus subtilis with a MIC value of $100 \mu \mathrm{g} / \mathrm{mL}$ compared with penicillin $(31 \mu \mathrm{g} / \mathrm{mL})$, against Pseudomonas aeruginosa with a MIC value of $125 \mu \mathrm{g} / \mathrm{mL}$ compared with penicillin $(46 \mu \mathrm{g} / \mathrm{mL})$, and against Streptomyces species with a MIC value of $125 \mu \mathrm{g} / \mathrm{mL}$ compared with penicillin $(33 \mu \mathrm{g} / \mathrm{mL})$ [49]. A series of substituted 
5,6,7,8-tetrahydro-3H-benzo[4,5]thieno[2,3-d]pyrimidine-4-one derivatives were synthesized and evaluated for antimicrobial activity against Escherichia coli, Bacillus subtilis, Staphylococcus aureus, Aspergillus niger and Candida albicans. The substituted thienopyrimidine derivative (48) was the most highly active compound [50].

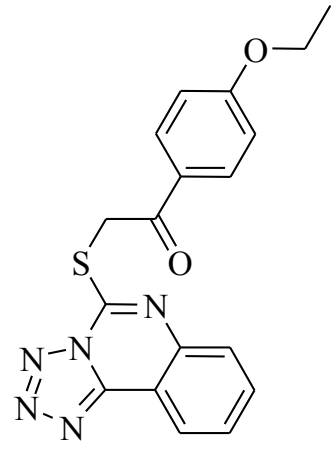

46

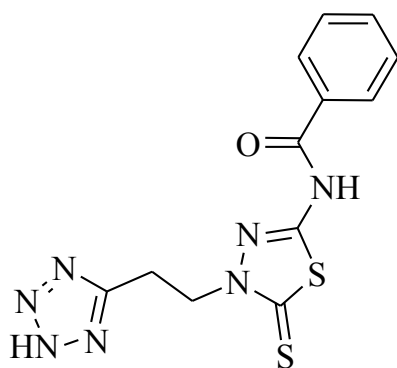

47

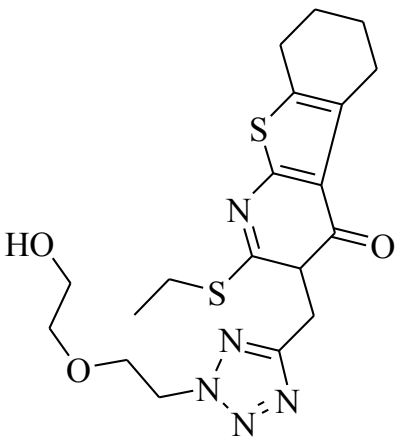

48

Figure 6. Structures of compounds 46-48.

A variety of triazole derivatives with a 5-substituted tetrazole structure were prepared (Figure 7) and evaluated for their antifungal activity against the Aspergillus spp, Cryptococcus neoformans, and Candida spp. in vitro. Some of these compounds possessed good antifungal activity against the different fungal cultures such as Candida species, C. neoformans and Aspergillus species. The location of the methyl group at the C-3 of compound $\mathbf{4 9}$ and $\mathbf{5 0}$ has been demonstrated to be a key structural element for antifungal potency [51]. It was reported that various 1-(2,4-dihydroxythiobenzoyl)imidazoles, -imidazolines and -tetrazoles were synthesized and evaluated for antibacterial properties. The MIC values against the Candida albicans ATCC 10231 strain, azole-resistant clinical isolates of C. albicans and non-Candida species were determined. Tetrazole derivatives $\mathbf{5 1}$ and $\mathbf{5 2}$ were the most active against $C$. albicans. All compounds showed higher activity than reference drugs itraconazole and fluconazole [52].

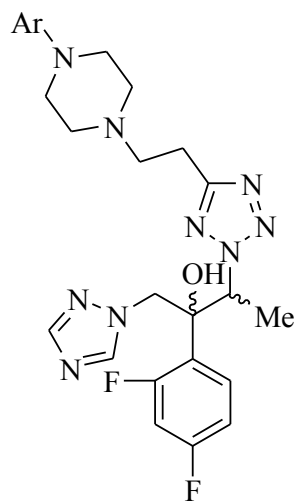

49

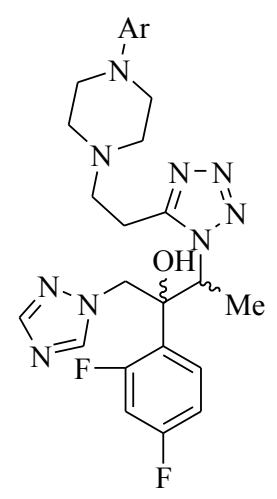

50<smiles>Oc1ccc(C(=S)n2nnnc2-c2ccc(Cl)cc2)c(O)c1</smiles>

51<smiles>CCOC(=O)Cc1nnnn1C(=S)c1ccc(O)cc1O</smiles>

52

Figure 7. Structures of compounds 49-52. 
Novel tetrazole derivatives containing azatidinone (Figure 8) were designed, synthesized and evaluated for antitubercular activity. The highest activity registered for compounds was $\mathbf{5 3}$ which should be regarded as a new hit for further development as a novel class of anti-Mycobacterium tuberculosis agents [53]. A series of tetrazole -earing acylhydrazone derivatives $\mathbf{5 4}$ were synthesized. Activity evaluation of some of these compounds showed anti-fungicidal activity [54]. A series of new 1-[(tetrazol-5-yl)methyl]indole derivatives were also synthesized. Compound $\mathbf{5 5}$ displayed strong activity against Escherichia coli, Bacillus subtilis, Streptococcus lactis and Pseudomonas sp., compared with ciprofloxacin and exhibited high activities against the tested fungi compared with fusidic acid, while compounds $\mathbf{5 6}$ and $\mathbf{5 7}$ showed strong activity against the Gram negative bacteria Escherichia coli and Pseudomonas aeruginosa [55]. New a-hydroxyphosphonate 58 and $a$-acetoxyphosphonate derivatives $\mathbf{5 9}$ were synthesized and their antimicrobial activities evaluated. All compounds demonstrated potent inhibition against all the strains tested [56].

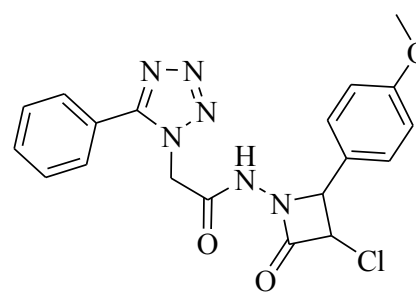

53

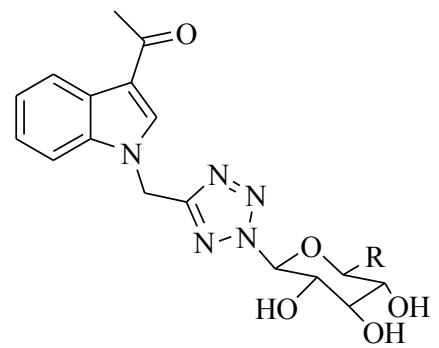

$56 \mathrm{R}=\mathrm{H}$

$57 \mathbf{R}=\mathrm{CH}_{2} \mathrm{OH}$<smiles>[R]c1ccc(/C=N/NC(=O)Cn2ncnc2-c2ccc(Cl)cc2)cc1</smiles>

54

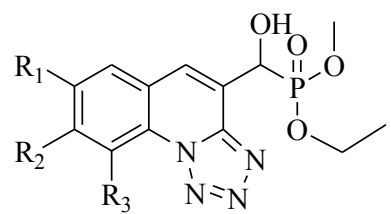

58

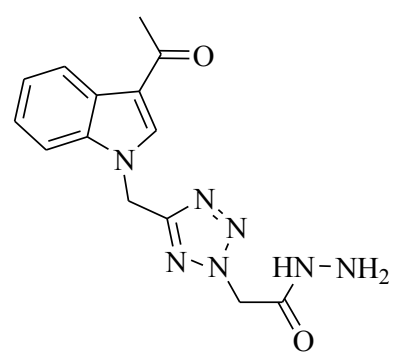

55

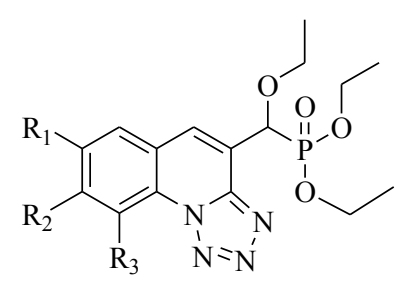

59

Figure 8. Structures of compounds 53-59.

\subsection{Anti-Inflammatory and Analgesic Activity}

It was reported that a series of 4,5-dihydro-1,5-diaryl- $1 H$-pyrazole-3-substituted-heteroazoles were designed and synthesized (Figure 9). All the compounds were screened for anti-inflammatory activity using the carrageenan-induced rat paw edema method. Diclofenac sodium was used as a standard drug for comparison. Compound $\mathbf{6 1}$ which is a tetrazole derivative was found to be the most potent anti-inflammatory compound in the present series as compared to the reference. Even the des-sulfonamide 1,2,4-oxadiazole derivatives 60, 61 showed good in vivo anti-inflammatory potency, meriting further attention in order to develop new leads in this series [57]. A new series of novel substituted tetrazole derivatives were prepared by reacting tetrazole with different types of carbazone derivatives and various substituted type of benzaldehyde were thus synthesized. All synthesized compounds were screened for anti-inflammatory activity in rats by the carrageenan-induced paw oedema method at a dose of $50 \mathrm{mg} / \mathrm{kg}$ body weight. All compounds showed moderate enhancement of the activity. Among 
the tested compound, compound $\mathbf{6 2}$ exhibited good potential anti-inflammatory activity when compared to the standard phenylbutazone (PBZ) at $5 \mathrm{mg} / \mathrm{kg} / \mathrm{po}$ [58]. Three series of tetrazolo[1,5-a]quinoline derivatives were synthesized. All the test compounds significantly inhibited granuloma formation. It could be safely concluded that the median effective dose (ED50) values of compounds 63, 64, 65 and 66 which range from 8.50 to $9.84 \mu \mathrm{mol}$ have anti-inflammatory activity comparable to that of indomethacin $\left(\mathrm{ED}_{50}\right.$ value $\left.=9.28 \mu \mathrm{mol}\right)$ [59].

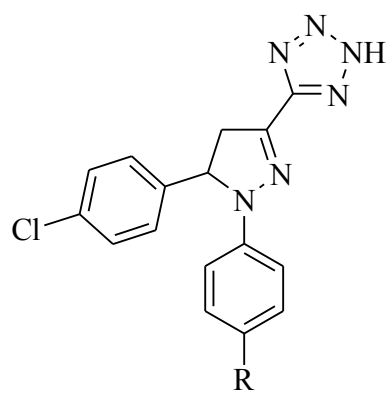

$60 \mathrm{R}=\mathrm{H}$

$61 \mathrm{R}=\mathrm{SO}_{2} \mathrm{NH}_{2}$<smiles>CN(C)C(=O)NNC(c1ccccc1)n1ncnn1</smiles>

62<smiles>[R]c1ccc(C2C(=O)/C(=C/c3ccc(N(C)C)cc3)C(=O)N(N=Cc3cc4ccccc4n4nnnc34)C2=S)cc1</smiles>

$63 \mathrm{R}=\mathrm{H}$

$64 \mathrm{R}=4-\mathrm{CH}_{3}$<smiles>[R]c1ccc(C2=NC(=S)NC(c3cc4ccccc4n4nnnc34)C2)cc1</smiles>

$65 \mathrm{R}=\mathrm{H}$

$66 \mathrm{R}=4-\mathrm{Br}$

Figure 9. Structures of compounds 60-66.

It was reported that a novel series of 1,5-diaryl-substituted tetrazole derivatives (Figure 10) were synthesized and evaluated for their anti-inflammatory activity. All tetrazoles showed half maximal (50\%) inhibitory concentration (IC50) values ranging from 0.42 to $8.1 \mathrm{mM}$ for COX-1 and 2.0 to $200 \mu \mathrm{M}$ for COX-2. The most potent compound $67\left(\mathrm{IC}_{50}(\mathrm{COX}-2)=2.0 \mu \mathrm{M}\right)$ was further used in molecular modeling docking studies [60]. New water-soluble, parenteral COX-2 inhibitor rofecoxib (compound 68) and celecoxib (compound 69) analogues were designed, synthesized and evaluated as selective cyclooxygenase-2 (COX-2) inhibitors with in vivo anti-inflammatory activity. The rofecoxib and celecoxib analogues 68 and 69 exhibited a high in vitro selectivity $\left(\mathbf{6 8}, \mathrm{COX}-1 \mathrm{IC}_{50}=3.8 \mathrm{nM}\right.$; COX-2 IC $_{50}=1.8 \mathrm{nM} ; \mathrm{SI}=2.11 ; 69, \mathrm{COX}-1 \mathrm{IC}_{50}=4.1 \mathrm{nM} ; \mathrm{COX}-2 \mathrm{IC}_{50}=1.9 \mathrm{nM} ; \mathrm{SI}=2.16$ ) relative to the reference drug celecoxib (COX-1 $\mathrm{IC}_{50}=3.7 \mathrm{nM}$; COX-2 $\mathrm{IC}_{50}=2.2 \mathrm{nM}$; SI $\left.=1.68\right)$ and also showed good anti-inflammatory activity in a carrageenan-induced rat paw edema assay and high aqueous solubility at $\mathrm{pH}$ values higher than 7 . Also 68 and 69 caused no significant damage to the gastric mucosa [61].

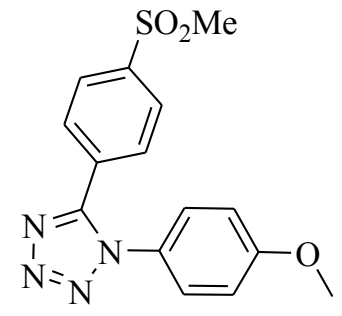

67

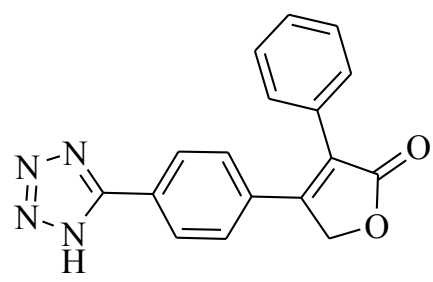

68

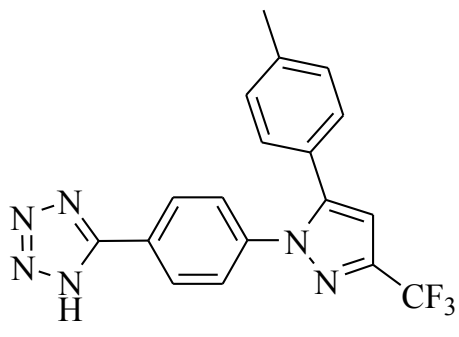

69

Figure 10. Structures of compounds 67-69. 
It was reported that a series of 5- and 6-membered carbocyclic and heterocyclic $\alpha$-hydroxy amide-derived bradykinin B1 antagonists bearing an $\mathrm{N}-2$ methyltetrazole as an oxadiazole replacement were prepared (Figure 11) and evaluated. A number of compounds with excellent B1 binding affinity, good pharmacokinetic properties, and desirable P-gp transport properties were discovered. In particular, compound $\mathbf{7 0}$ exhibited excellent binding affinity $(\mathrm{hKi}=0.41 \mathrm{nM}), \mathrm{P}$-gp transport, and dog pharmacokinetic profiles ( $\mathrm{F}=91 \%$ ) [62]. Various 1-[5-(substituted phenyl)-1-phenyl-4,5-dihydro- $1 \mathrm{H}$ pyrazol-3-yl]-5-phenyl- $1 H$-tetrazoles were also synthesized. All the compounds exhibited weak to potent anti-inflammatory activity. The compounds $\mathbf{7 1}$ and $\mathbf{7 2}$ possessed potent anti-inflammatory activity in comparison with ibuprofen [63]. A series of selective $\mathrm{P}_{2} \mathrm{X}_{7}$ receptor antagonists for chronic inflammation and pain ATP, acting on $\mathrm{P}_{2} \mathrm{X}_{7}$ receptors was reported. Although highly potent compounds such as compound $\mathbf{7 3}$ were discovered, the poor physiochemical properties of these molecules led to an investigation of heterocyclic attachments that might confer improved properties in this regard [64].

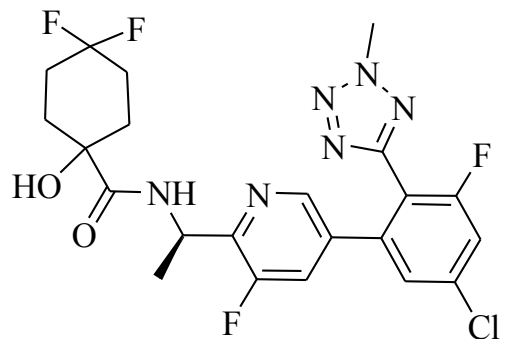

70

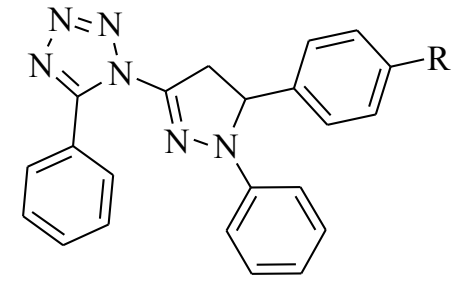

$71 \mathbf{R}=\mathbf{H}$

$72 \mathrm{R}=\mathrm{OCH}_{3}$<smiles>Cc1ccccc1Cn1nnnc1-c1cccc(Cl)c1Cl</smiles>

73

Figure 11. Structures of compounds 70-73.

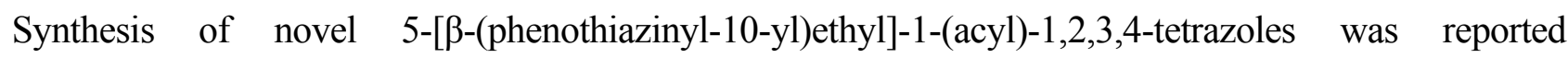
(Figure 12). The synthesized compounds were screened for analgesic and anti-inflammatory activity. Out of the 12 compounds synthesized, compounds $\mathbf{7 4}$ and $\mathbf{7 5}$ showed promising analgesic activity, while compounds $\mathbf{7 6}$ and $\mathbf{7 7}$ showed promising anti-inflammatory activity [65].
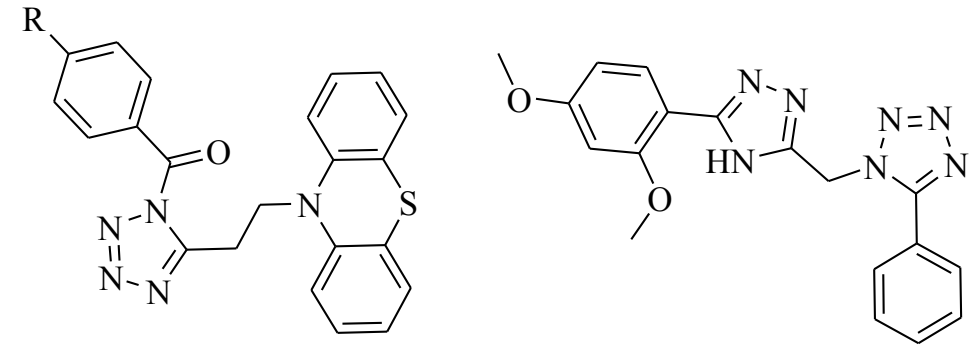

$74 \mathrm{R}=\mathrm{H}$

$75 \mathrm{R}=\mathrm{CH}_{3} \quad 77 \quad \mathrm{R}=\mathrm{NO}$

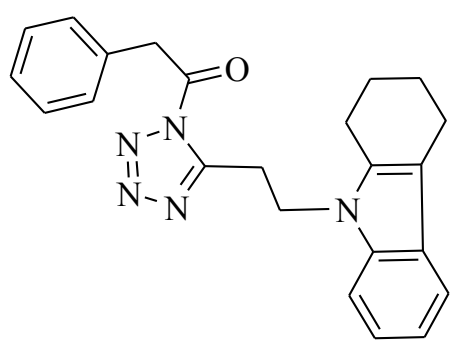

79

Figure 12. Structures of compounds 74-79.

1,2,4-Triazole derivatives containing pyrazole, tetrazole, isoxazole and pyrimidine rings were synthesized and evaluated for analgesic activity in vivo. The hot plate and acetic acid induced writhing methods have been described to study analgesic activity. Compound $\mathbf{7 8}$ exhibited comparative 
analgesic properties (up to $60 \%$ protection) to the standard drug ibuprofen (66\%). The analgesic activity measured by the central nervous system analgesic pentazocine $(5 \mathrm{mg} / \mathrm{kg})$ significantly increased the hot plate latency producing a highest \% MPE at 69.02. Compound 78 had $60.62 \%$ MPE [66]. Twelve different derivatives of substituted-\{5-[2-(1,2,3,4-tetrahydrocarbazol-9yl)ethyl]tetrazol-1-yl alkanones were synthesized. The compounds were screened for antinociceptive activity by the acetic acid induced writhing method and hot plate method. Compound $\mathbf{7 9}$ was found to be the most active compound of the series [67].

\subsection{Anticancer Activity}

It was reported that a series of new tetrazole derivatives were synthesized from Baylis-Hillman allyl amines in a clean, efficient and straightforward manner (Figure 13). Compound $\mathbf{8 0}$ was found particularly more active against liver carcinoma (Hep G2) and lung adenocarcinoma (A 549) cancer cell lines, while compound $\mathbf{8 0}$ also displayed significant activity against prostate (DU 145) cancer cell line. The hit compound $\mathbf{8 0}$ could bind to DNA and form a stable complex and may act as a potential genotoxic agent for cancer therapy [68].

New (tetrazol-5-yl)methylindole derivatives were synthesized from 2-phenylindole. The synthesized compounds were studied for their anticancer activity against the human liver carcinoma cell line HepG2 and the results showed that compound $\mathbf{8 1}$ was highly active among the series of tested compounds and it affected the cell viability in a dose dependent manner with an $\mathrm{IC}_{50}$ value of 4.2 $\mu \mathrm{M}$ [69]. Two series of 1,5-diaryl-substituted-1,2,3,4-tetrazoles were concisely synthesized. Several of the synthesized compounds also had effective activity in inhibiting the growth of multidrug resistant cells overexpressed P-glycoprotein. Compound $\mathbf{8 2}$ was a strong inhibitor of tubulin polymerization $\left(\mathrm{IC}_{50}=1.1 \mu \mathrm{M}\right)$ and strongly inhibited the binding of colchicine to tubulin $(78 \%$ inhibition). The results demonstrated that $\mathbf{8 2}$ is a promising new tubulin binding agent worthy of further evaluation as a potential chemotherapeutic agent [70].

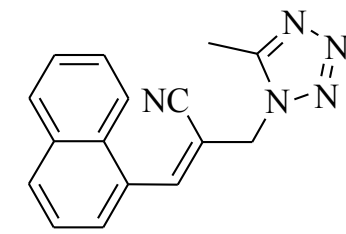

$\mathbf{8 0}$

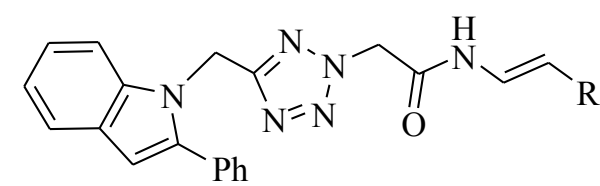

$81 \mathrm{R}=\mathrm{D}$-mannopentitolyl

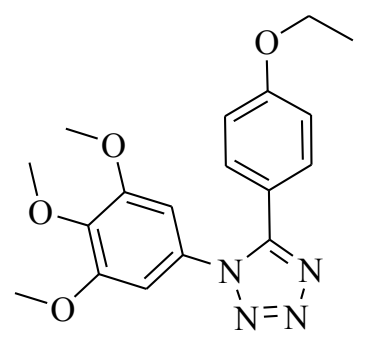

82

Figure 13. Structures of compounds 80-82.

It was reported that a synthesis of several D-ring-substituted steroidal tetrazoles were prepared by means of 1,3-dipolar cycloadditions (Figure 14). The novel synthesized compounds were screened for their activities against a panel of three human gynecological cancer cell lines (HeLa, MCF7 and A2780). The study showed that of all these compounds only $\mathbf{8 3}$ had a moderate effect [71]. Some new spirothieno[2,3- $d]$ pyrimidine, imidazolidine, substituted pyrimidinyl and substituted thiazolidine thieno[2,3- $d]$ prymidine derivatives were synthesized. The combination of the potent anticancer activity 
of compounds 84 and 85 with their less toxicity and the ease of synthesis makes them the promising lead compounds for cancer chemotherapy [72].<smiles>C[C@]12CC[C@@H](O)CC1=CC[C@@H]1C2CC[C@]2(C)[C@H]1C[C@H](C[C@H]1C=CC=C1C(=O)c1ccccc1)[C@H]2O</smiles>

83<smiles>COc1ccc(C2SCC(=O)N2Nc2nc3sc4c(c3c(=O)n2N)CCCC4)cc1</smiles>

84

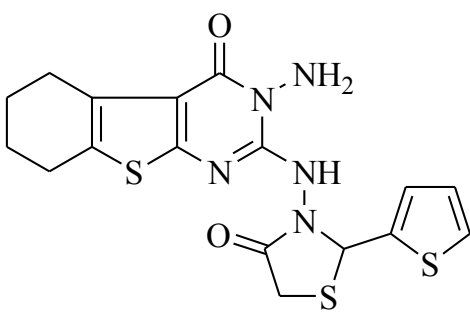

85

Figure 14. Structures of compounds 83-85.

Jackman et al., reported a drug ZD9331 (86 in Figure 15) which exhibits potent growth inhibitory and cytotoxic activity. The results suggested that ZD9331 would have a different, or at least an incompletely overlapping spectrum of antitumor activity and toxicity profile, compared with tomudex and possibly other TS inhibitors currently being studied clinically [73].<smiles>C#CN(Cc1cc2c(=O)[nH]c(C)nc2cc1C)c1ccc(C(=O)N[C](CCc2nnn[nH]2)C(=O)O)c(F)c1</smiles>

86

Figure 15. Structure of compound $\mathbf{8 6 .}$

A series of new 1,2-substituted tetrazole derivatives were synthesized and evaluated on MCF-7 (ER positive), MDA-MB-231 and ZR-75 (ER negative) breast cancer cell lines. Compounds 87, 88 and 89 showed higher inhibitory effects on MCF-7 cells, whereas compound $\mathbf{9 0}$ exhibited a higher inhibition on MDA-MB-231 cells and ZR-75 cells at a concentration of $10^{-5} \mathrm{M}$. To know if the compounds are selectively targeting specific cancers, they were screened against the HepG2 cell line. Only 1\%-10\% inhibition was found at $10^{-5} \mathrm{M}$ concentration [74]. A series of 1,5-disubstituted tetrazole-tethered combretastatin analogues were developed and evaluated for their antitubulin and antiproliferative activity. Compounds 91 and 92, having hydrogen-bonding donor groups at the ortho- and meta-positions on the 4-methoxyphenyl B ring, are strong inhibitors of tubulin polymerization and antiproliferative agents having $\mathrm{IC}_{50}$ values in micromolar concentrations [75].

A novel synthetic molecule 7a-aza-B-homostigmast-5-eno[7a,7-d] tetrazole was reported (Figure 16). The compound $\mathbf{9 3}$ was tested against two human cancer cell lines: CT116 and HepG2 and one non-cancerous HFL1 (human lung fibroblast) cell line. The $\mathrm{IC}_{50}$ values for all compounds were compared to doxorubicin. The results indicated that the compound $\mathbf{9 3}$ inhibited the various cancer cell lines in a dose-dependent manner and effectively inhibited cancer cell growth [76]. 
<smiles>[R]c1cccc(/C=N/NC(=O)Cn2nnnc2-c2ccc3c(c2)OCO3)c1</smiles>

$87 \quad \mathrm{R}=2-\mathrm{NO}_{2} \quad 89 \quad \mathrm{R}=4-\mathrm{NO}_{2}$

$88 \mathrm{R}=3-\mathrm{NO}_{2} \quad 90 \mathrm{R}=2,4-\mathrm{diOCH}_{3}$

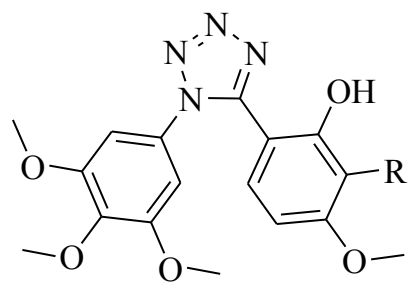

$91 \mathrm{R}=\mathrm{OH} \quad 92 \mathrm{R}=\mathrm{NH}_{2}$

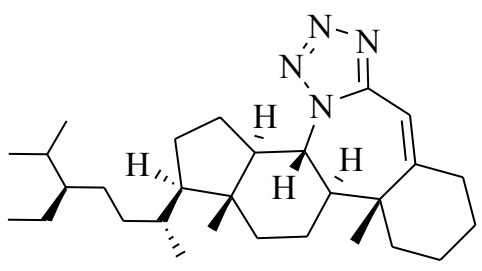

93

Figure 16. Structures of compounds 87-93.

\subsection{Anticonvulsant Activity}

A potent inactivator of GABA-AT was synthesized (Figure 17), which was shown to be a time- and concentration-dependent GABA-AT inhibitor. The study found low brain levels of the inhibitory neurotransmitter $\gamma$-aminobutyric acid (GABA) can lead to seizure. Inhibition of GABA aminotransferase can increase the concentration of GABA and can terminate the convulsions. The $\mathrm{K}_{\text {inact }} / \mathrm{KI}$ value for compound 94 was calculated to be $0.28 \mathrm{~min}^{-1} \cdot \mathrm{mM}^{-1}$. Compound 94 also showed good lipophilicity $(\mathrm{C} \log \mathrm{P}=-0.48)$ [77]. A new series of substituted tetrazoles were reported where all the synthesized compounds exhibited anticonvulsant activity against subcutaneous metrazole (ScMet) and maximal electroshock (MES) induced seizures in mice. Compounds 95 and 96 proved to be the most active compounds in this study, with special high activity in the ScMet test (\% protection: 100\% and $80 \%$, respectively) [78].

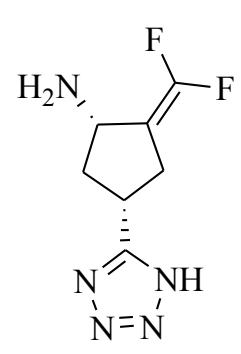

94<smiles>CC(c1ccccc1)c1nnnn1CC(O)c1ccc(Cl)cc1</smiles>

95<smiles>O=C(COC(Cn1nnnc1-c1ccccc1)c1ccc(Cl)cc1)NNC(=S)Nc1ccccc1</smiles>

96<smiles></smiles><smiles>Clc1ccc(Oc2nn3nnnc3c3ccccc23)cc1</smiles>

Figure 17. Structures of compounds 94-99.

A series of 5-alkoxytetrazolo-[1,5-c]thieno[2,3-e]pyrimidine derivatives were synthesized and evaluated for anticonvulsant activities. The pharmacological results showed that only four of the synthesized compounds had weak anticonvulsant activity. The more active compounds were $\mathbf{9 7}$ and 
98 [79]. A new series of 6-alkyoxytetrazolo[5,1-a]phthalazine derivatives was synthesized and their anticonvulsant activity evaluated. The pharmacological results showed that compound 99 was the most potential agent, with an $\mathrm{ED}_{50}$ value of $6.8 \mathrm{mg} / \mathrm{kg}$ and a TD 50 value of $456.4 \mathrm{mg} / \mathrm{kg}$. The protective index (PI $\left.=\mathrm{TD}_{50} / \mathrm{ED}_{50}\right)$ for compound 99 was 67.1, which was significantly higher than that for the reference drug carbamazepine (PI $=6.4)$ [80]. In our laboratory studies of antiepileptic drugs, this was found to be the best active compound in ten years. It is in preclinical stages and is expected to be eventually registered as an approved drug.

\subsection{Antihypertensive Activity}

A novel nonpeptide angiotensin $\mathrm{AT}_{1}$ receptor antagonist was reported (Figure 18). The pharmacology results demonstrated that compound $\mathbf{1 0 0}$ inhibited $\left[{ }^{125} \mathrm{I}\right]$ angiotensin II binding to $\mathrm{AT}_{1}$ receptors in rat liver membranes $\left(\mathrm{K}_{\mathrm{i}}=2.5 \pm 0.5 \mathrm{nM}\right)$ and did not interact with $\mathrm{AT}_{2}$ receptors in bovine cerebellar membranes. Compound $\mathbf{1 0 0}$ inhibited the contractile response to angiotensin II (pD(2)' values: 7.43 and 7.29, respectively) with a significant reduction in the maximum. The study suggested that compound $\mathbf{1 0 0}$ may be useful for treatment of hypertension [81,82]. An angiotensin II receptor antagonist which is selectivity for the AT1 receptor subtype was also reported. The concentration of compound 101 that inhibited the binding of $\left[{ }^{125} \mathrm{I}\right]$ Ang II to the $\mathrm{AT}_{1}$ receptor from rat adrenal cortex by $50 \%\left(\mathrm{IC}_{50}\right)$ was $0.13 \mathrm{nM}$, compared with $80.0 \mathrm{nM}$ for losartan. Compound 101 showed excellent inhibitory activity in the contraction of isolated rabbit thoracic aorta contrasted with other ARBs such as losartan and candesartan. The antihypertensive effect of compound $\mathbf{1 0 1}$ was also verified to be maintained for $24 \mathrm{~h}[83,84]$. Arhancet et al., reported the structure-activity relationships of the novel series of cyanoester dihydropyridines. Compound $\mathbf{1 0 2}$ showed improved in vitro metabolic stability and solubility without CYP inhibition liability. On the basis of its MR potency and favorable in vitro pharmacokinetic profile, with its moderate clearance and good half-life, compound $\mathbf{1 0 2}$ might be a suitable candidate for in vivo efficacy studies [85].

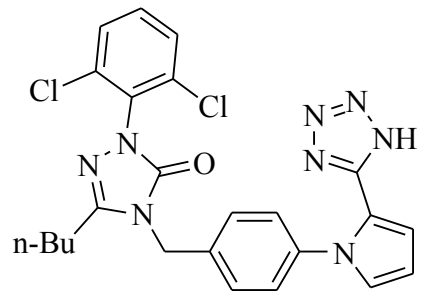

100

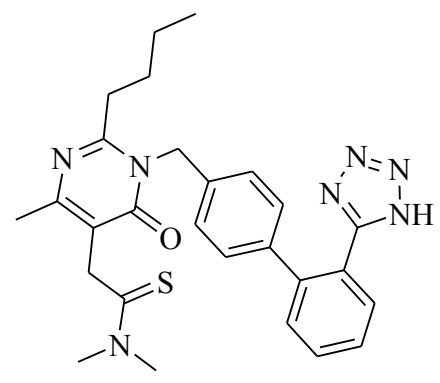

101

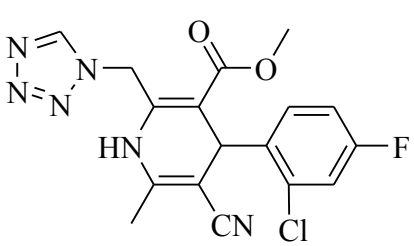

102

Figure 18. Structures of compounds 100-102.

\subsection{Hypoglycemic Activity}

Novel tetrazole-bearing N-glycosides were designed and synthesized as SGLT2 inhibitors (Figure 19). Their hypoglycemic activity has been tested in vivo by a mice oral glucose tolerance test (OGTT). Two compounds were found to be more potent than the positive control dapagliflozin. The inhibition rates of blood glucose levels in mice OGTT for compounds $\mathbf{1 0 3}$ and $\mathbf{1 0 4}$ were $73.9 \%$ and $77.0 \%$ as 
compared with dapagliflozin (68.3\%) [86]. Momose et al. prepared a series of 5-(4-alkoxyphenylalkyl)- $1 H$-tetrazole derivatives and evaluated their antidiabetic effects in two genetically obese and diabetic animal models, $\mathrm{KKA}^{\mathrm{y}}$ mice and Wistar fatty rats. A large number of the compounds showed potent glucose and lipid lowering activities in $\mathrm{KKA}^{\mathrm{y}}$ mice. In particular, compound $\mathbf{1 0 5}$ had potent glucose lowering activity $\left(\mathrm{ED}_{25}=0.0839 \mathrm{mg} \cdot \mathrm{kg}^{-1} \cdot \mathrm{d}^{-1}\right)$, being 72 times more active than pioglitazone hydrochloride $\left(\mathrm{ED}_{25}=6.0 \mathrm{mg} \cdot \mathrm{kg}^{-1} \cdot \mathrm{d}^{-1}\right)$. This compound also showed strong glucose lowering $\left(E D_{25}=0.0873 \mathrm{mg} \cdot \mathrm{kg}^{-1} \cdot \mathrm{d}^{-1}\right)$ and lipid lowering effects $\left(E_{25}=0.0277 \mathrm{mg} \cdot \mathrm{kg}^{-1} \cdot \mathrm{d}^{-1}\right)$ in Wistar fatty rats. The antidiabetic effects of the compound $\mathbf{1 0 5}$ are considered to be due to its potent agonistic activity $\left(\mathrm{EC}_{50}=6.75 \mathrm{nM}\right)$ for peroxisome proliferator-activated receptor $(\mathrm{PPAR} \gamma)$ [87]. Pegklidou et al., synthesized a novel series of pyrrole based on chemotypes and evaluated their activity as selective aldose reductase inhibitors. The data indicated that the presented chemotypes 106 and 107 are promising lead compounds for the development of selective aldose reductase inhibitors, targeting the long-term complications of diabetes mellitus [88].

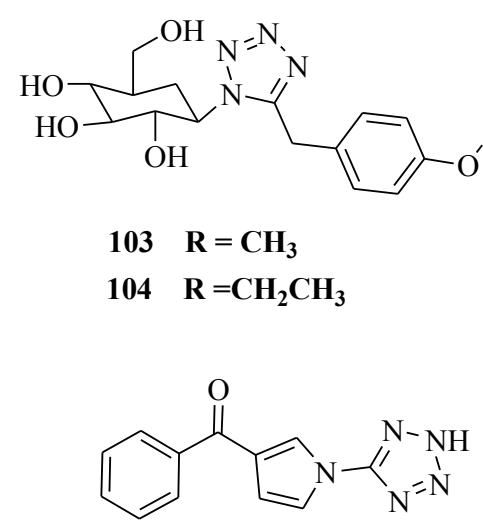

106<smiles>Cc1oc(-c2ccccc2)nc1COc1ccc(CCCc2nnn[nH]2)cn1</smiles>

105

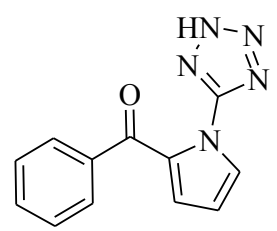

107

Figure 19. Structures of compounds 105-107.

\subsection{Antiparasitic Activity}

A series of compounds bearing a tetrazole and triazine ring structures conjugated with a $\mathrm{SO}_{2} \mathrm{NH}$ function were synthesized (Figure 20) and tested for their antiamoebic activity. Compounds 108 and 109 were the least cytotoxic $\left(\mathrm{IC}_{50}>100 \mu \mathrm{M}\right)$ and excellent Entamoeba histolytica inhibitors with $\mathrm{IC}_{50}$ values of $1.05 \mu \mathrm{M}$ and $1.02 \mu \mathrm{M}$, respectively [89]. A novel series of pyrazoline derivatives were synthesized and screened in vitro to determine the effect on the growth of HM1:IMSS strain of Entamoeba histolytica. Compound $\mathbf{1 1 0}$ had potent antiamoebic activity $\left(\mathrm{IC}_{50}=0.86 \mu \mathrm{M}\right)$, the least cytotoxicity $\left(\mathrm{IC}_{50}=>100 \mu \mathrm{M}\right)$ and safety index value of $>116.28$, which was nearly twice better than metronidazole $\left(\mathrm{IC}_{50}>55.55 \mu \mathrm{M}\right)$ [90]. A new series of 5-(1-aryl-3-methyl-1H-pyrazol-4-yl)- $1 H$ tetrazole derivatives and their precursor 1-aryl-3-methyl-1H-pyrazole-4-carbonitriles were synthesized and evaluated as in vitro antileishmanials against Leishmania braziliensis and Leishmania amazonensis promastigotes. In parallel, the cytotoxicity of these compounds was evaluated on the RAW 264.7 cell line. The results showed that among the assayed compounds the substituted 3-chlorophenyl (compound 111) $\left(\mathrm{IC}_{50} / 24 \mathrm{~h}=15 \pm 0.14 \mu \mathrm{M}\right)$ and 3,4-dichlorophenyl (compound 112) ( $\mathrm{IC}_{50} / 24 \mathrm{~h}=26 \pm 0.09 \mu \mathrm{M}$ ) 
tetrazoles were the most potent against L. braziliensis promastigotes, as compared with the reference drug pentamidine, which presented $\mathrm{IC}_{50}=13 \pm 0.04 \mu \mathrm{M}$. In addition, compound 111 and 112 were less cytotoxic than pentamidine [91].
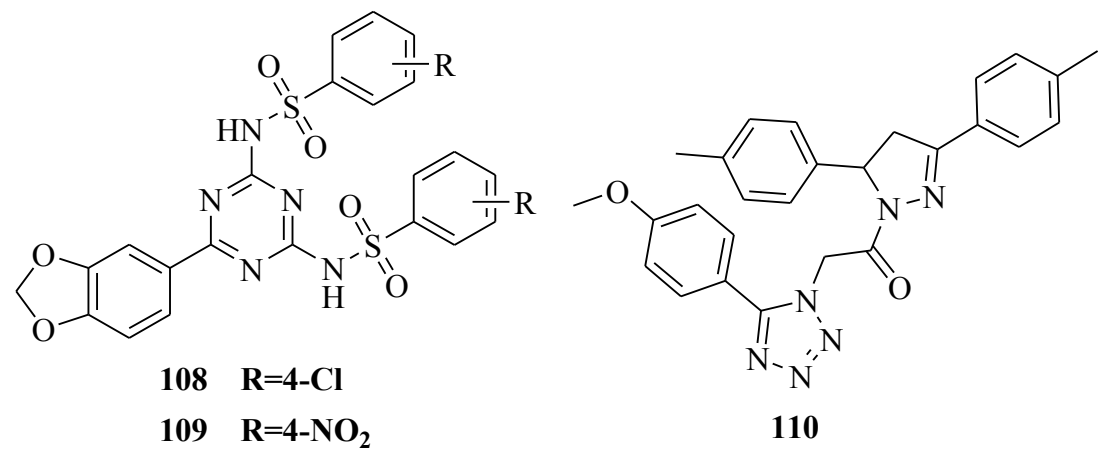

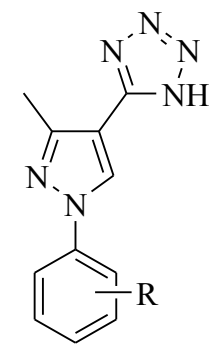

$111 \mathrm{R}=3-\mathrm{Cl}$

$112 \mathrm{R}=3,4-\mathrm{diCl}$

Figure 20. Structures of compounds 108-112.

\subsection{Antiviral Activity}

Hutchinson and Naylor prepared 5-(phosphonomethyl)-1H-tetrazole and a number of related tetrazoles (Figure 21) and investigated their effects on the replication of Herpes Simplex Viruses-1 and -2 as well as their abilities to inhibit the DNA polymerases induced by these viruses and the RNA transcriptase activity of influenza virus A. The thio-analogue 113 was a good chelator of zinc ions $\left(\mathrm{pK}_{\mathrm{d}^{\prime}}>6\right.$, the determination of $\mathrm{pK}_{\mathrm{d}^{\prime}}$ values related to the strength of binding of zinc ions to phosphonates was by gel filtration) and was a more effective inhibitor of HSV-1 DNA polymerase and influenza RNA tranlscriptase [92]. A series of novel tetrazoles containing 1,2,3-thiadiazole derivatives were sythesized. The bioassay tests indicated that most of the target compounds had higher anti-TMV activity than that of ribavirin at $100 \mu \mathrm{g} / \mathrm{mL}$. Compounds 114, 115 and 116 also showed equivalent protection effect to ribavirin in vivo at $100 \mu \mathrm{g} / \mathrm{mL}$. These studies indicated that the newly synthesized tetrazole-containing 1,2,3-thiadiazole derivatives possessed good potential bioactivities, and were worthy of further study in pesticide development [93]. 7-(2H-Tetrazol-5-yl)-1H-indole (117) was found to be a potent inhibitor of HIV-1 attachment but the compound was lack of oral bioavailability in rats. The cause of the low exposure was believed to be poor absorption attributed to the acidic nature of the tetrazole moiety $[94,95]$.

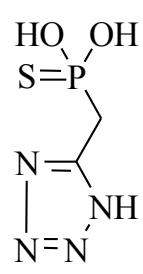

113<smiles>[R]NC(c1snnc1C)c1nnnn1C1CCCCC1</smiles>

$114 \mathrm{R}=$ =isopropyl $115 R=$ cyclopropyl $116 R=2-f l u o r o p h e n y l$ $116 \mathrm{R}=2$-fluorophenyl<smiles>O=C(C(=O)N1CCN(C(=O)c2ccccc2)CC1)c1c[nH]c2c(-c3nn[nH]n3)ccc(F)c12</smiles>

117

Figure 21. Structures of compounds 113-117. 


\subsection{Other Miscellaneous Activities}

Other tetrazolium compounds that have miscellaneous activities were synthesized (Figures 22 and 23). Karabanovich et al., reported a new class of highly potent antituberculosis agents, 1-substituted-5[(3,5-dinitrobenzyl)sulfanyl]-1H-tetrazoles 118 and their oxa- and selenyl-analogs 119 and 120. Antimycobacterial activities reached MIC values of $1 \mu \mathrm{M}$ against M. tuberculosis CNCTC My 331/88 and $0.25-1 \mu \mathrm{M}$ against six multi-drug resistant clinically isolated strains of $M$. tuberculosis; these compounds also exhibited no cross-resistance with common anti-TB drugs. Furthermore, these compounds possessed similar activity towards both INH-susceptible and INH-resistant strains of non-tuberculous M. kansasii. Moreover, compounds of series 118, 119 and 120 exhibited highly selective antimycobacterial effects because they exhibit no antibacterial or antifungal effects and exhibit low toxicity on selected mammalian cell lines with $\mathrm{IC}_{50}$ values upwards of $30 \mu \mathrm{M}$ [96]. Kikuchi et al., investigated an antiglaucoma ophthalmic agent $\mathbf{1 2 1}$ which is an angiotensin AT1 receptor antagonist with a molecular weight of approximately 446. The studies revealed that compound $\mathbf{1 2 1}$ exhibits a solubilizing effect upon insoluble additives as generally seen in detergents. Furthermore, in vitro permeability across rabbit corneal membrane for compound $\mathbf{1 2 1}$ decreased at higher concentrations [97]. Adibi et al., sythesized a series of catecholthioethers having benzoxazole and tetrazole moieties. The antioxidant activity was assessed using two methods, including 1,1-biphenyl-2-picrylhydrazyl (DPPH) radical scavenging and reducing power assays according to the methods described in the literature. All the synthesized compounds except one exhibited very good antioxidant properties. They were also more potent than BHA and Trolox used as reference compounds. The $\mathrm{IC}_{50}$ of compound $\mathbf{1 2 2}$ that the best for antioxidant activity among tetrazolium compounds, with a value of 0.17 . Furthermore, 122 could inhibit in vitro growth of Candida albicans having the same inhibitory activity as fluconazole (MIC value $4 \mathrm{mg} / \mathrm{mL}$ ) [98]. Singh et al. synthesized several regioisomeric tetrazolylindole derivatives and screened them for their ER binding affinity, agonist (estrogenic), antagonist (antiestrogenic) and anti-implantation activities. Compound $\mathbf{1 2 3}$ showed $100 \%$ contraceptive efficacy at $10 \mathrm{mg} / \mathrm{kg}$ dose. At a lower dose of $5 \mathrm{mg} / \mathrm{kg}$, it was only $67 \%$ effective however [99]. Li et al., prepared a novel series of N1 substituted tetrazole amides and showed them to be potent growth hormone (GH) secretagogues. Among them, the most potent analog $124\left(\mathrm{EC}_{50}=0.2 \mathrm{nM}\right)$ showed an increase in plasma GH levels of approximately 10-fold in an anesthetized IV rat model [100].

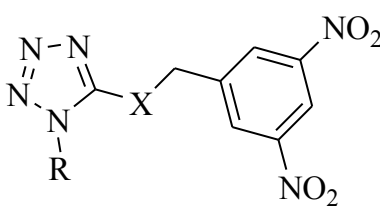

$118 \mathrm{X}=\mathrm{S}$

$119 X=O$

$120 \mathrm{X}=\mathrm{Se}$

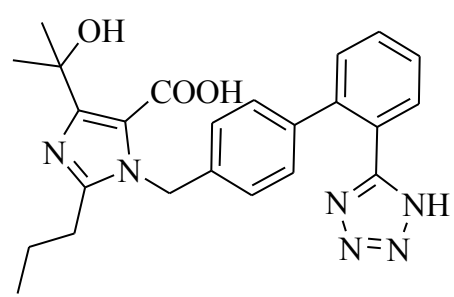

121

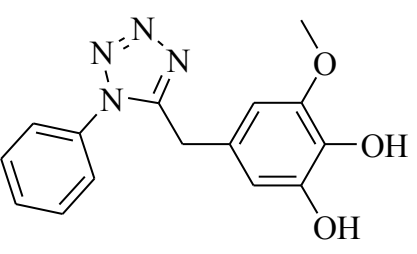

122

Figure 22. Structures of compounds 118-122. 


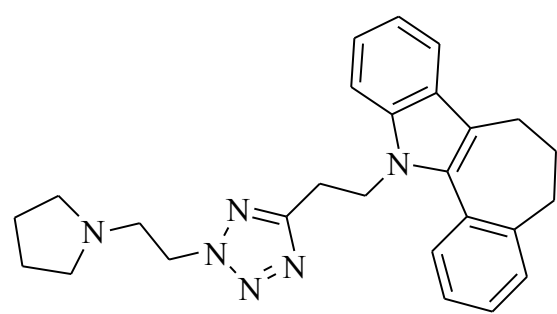

123

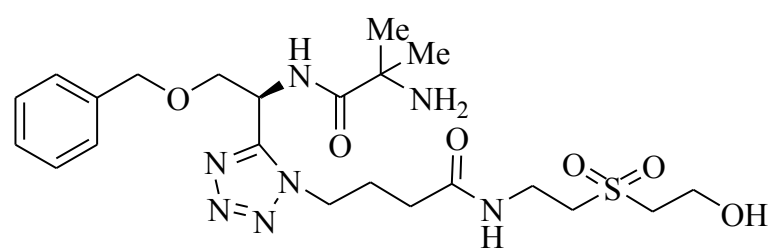

124

Figure 23. Structures of compounds 123-124.

\section{Conclusions}

All in all, some general synthetic methods, new methods of synthesis and improvements to existing procedures have been introduced that make the preparation of many tetrazole derivatives facile and efficient. This review has emphasized the diverse pharmacological properties associated with substituted tetrazoles. As evidenced by the present literature, we can find that tetrazole derivatives are a significant class of heterocyclic compounds. We firmly believe that modifications of the tetrazole moiety must help us find even more valuable biological activities. We hope that in the future more activities of tetrazole can be found and used in the field of medical sciences.

\section{Acknowledgments}

This work was support by Inner Mongolia Natural Science Foundation (No. 2012MS1165) and the doctoral scientific research foundation of Inner Mongolia University for the Nationalities (No. BS290).

\section{Author Contributions}

Cheng-Xi Wei and Ming Bian did equal work on researching the literature and writing the paper. Guo-Hua Gong directed the work and corrected the manuscript.

\section{Conflicts of Interest}

The authors declare no conflict of interest.

\section{References}

1. Jonassen, H.B.; Nelson, J.H.; Schmitt, D.L.; Henry, R.A.; Moore, D.W. Platinum- and palladium-tetrazole complexes. Inorg. Chem. 1970, 9, 2678-2681.

2. Katritsky, A.R., Rees, C.W., Potts, K.T., Eds. Comprehensive Heterocyclic Chemistry: The Structurt, Reactions, Synthesis and Uses of Heterocyclic Compounds, 1st ed.; Pergamon Press: Oxford, UK, 1984; Volume 5, Part 4A, pp. 791-838.

3. Su, W.K.; Hong, Z.; Shan, W.G.; Zhang, X.X. A facile synthesis of 1-substituted-1H-1,2,3,4tetrazoles catalyzed by ytterbium triflate hydrate. Eur. J. Org. Chem. 2006, 37, 2723-2726.

4. Benson, F.R. Theoretical principles of the chemistry of heterocycles. In Heterocylic Compounds; John Wiley \& Sons, Inc.: New York, NY, USA, 1967; p. 1. 
5. Demko, Z.P.; Sharpless, K.B. Preparation of 5-substituted-1H-tetrazoles from nitriles in water. J. Org. Chem. 2001, 66, 7945-7950.

6. Berghmans, S.; Hunt, J.; Roach, A.; Goldsmith, P. Zebrafish offer the potential for a primary screen to identify a wide variety of potential anticonvulsants. Epilepsy Res. 2007, 75, 18-28.

7. Toney, J.H.; Fitzgerald, P.M.; Grover-Sharma, N.; Olson, S.H.; May, W.J.; Sundelof, J.G.; Vanderwall, D.E.; Cleary, K.A.; Grant, S.K.; Wu, J.K.; et al. Antibiotic sensitization using biphenyl tetrazoles as potent inhibitors of Bacteroides fragilis metallo-beta-lactamase. Chem. Biol. 1998, 5, 185-196.

8. Butter, R.N. Tetrazoles. In Comprehensive Heterocyclic Chemistry; Katritzky, A.R., Rees, C.W., Eds.; Pergamon Press: New York, NY, USA, 1984; Volume 5, Part 4A, p. 791.

9. Tamura, Y.; Watanabe, F.; Nakatani, T.; Yasui, K.; Fuji, M.; Komurasaki, T.; Tsuzuki, H.; Maekawa, R.; Yoshioka, T.; Kawada, K.; et al. Highly selective and orally active inhibitors of type IV collagenase (MMP-9 and MMP-2): $N$-sulfonylamino acid derivatives. J. Med. Chem. 1998, 41, 640-649.

10. Dighe, S.N.; Jain, K.S.; Srinivasan, K.V. A novel synthesis of 1-aryl tetrazoles promoted by employing the synergy of the combined use of DMSO and an ionic liquid as the solvent system at ambient temperature. Tetrahedron Lett. 2009, 50, 6139-6142.

11. Palimkar, S.S.; Siddiqui, S.A.; Daniel, T.; Lahoti, R.J.; Srinivasan, K.V. Ionic liquid-promoted regiospecific Friedlander annulation: Novel synthesis of quinolines and fused polycyclic quinolines. J. Org. Chem. 2003, 68, 9371-9378.

12. Esmaeilpour, M.; Javidi, J.; Dodeji, F.N.; Abarghoui, M.M. Facile synthesis of 1- and 5 -substituted $1 H$-tetrazoles catalyzed by recyclable ligand complex of copper(II) supported on superparamagnetic $\mathrm{Fe}_{3} \mathrm{O}_{4} @ \mathrm{SiO}_{2}$ nanoparticles. J. Mol. Catal. A-Chem. 2014, 393, 18-29.

13. Jin, T.; Kamijo, S.; Yamamoto, Y. Synthesis of 1-substituted tetrazoles via the acid-catalyzed [3+2] cycloaddition between isocyanides and trimethylsilyl azide. Tetrahedron Lett. 2004, 45, 9435-9437.

14. Medda, F.; Hulme, C. A facile and rapid route for the synthesis of novel 1,5-substituted tetrazole hydantoins and thiohydantoins via a TMSN3-Ugi/RNCX cyclization. Tetrahedron Lett. 2012, 53, 5593-5596.

15. Bond, A.D.; Fleming, A.; Gaire, J.; Kelleher, F.; McGinley, J.; McKee, V.; Sheridan, U. Coordination studies of copper (II), cobalt (II) and iron (II) with isomeric pyridyltetrazole ligands. Polyhedron 2012, 33, 289-296.

16. Amanpour, T.; Mirzaei, P.; Bazgir, A. Isocyanide-based four-component synthesis of ferrocenyl 1,5-disubstituted tetrazoles. Tetrahedron Lett. 2012, 53, 1421-1423.

17. Mohite, P.B.; Pandhare, R.B.; Khanage, S.G.; Bhaskara, V.H. A novel approach for the synthesis of substituted tetrazoles. Dig. J. Nanomater. Biostruct. 2009, 4, 803-807.

18. Wang, W.X.; Cai, H.L.; Xiong, R.G. Hydrothermal synthesis method of 5-(4'-methylbiphenyl-2yl)-1H-tetrazole. Chin. Chem. Lett. 2013, 24, 783-785.

19. Dabbagh, H.A.; Chermahini, A.; Banibairami, S. A new family of bis-tetrazole (BIZOL) BINOL-type ligands. Tetrahedron Lett. 2006, 47, 3929-3932.

20. Wittenberger, S.J. Recent developments in tetrazole chemistry. A review. Org. Prep. Proced. Int. 1994, 26, 499-531. 
21. Wittenberger, S.J.; Donner, B.G. Dialkyltin oxide mediated addition of trimethylsilyl azide to nitriles. A novel preparation of 5-substituted tetrazols. J. Org. Chem. 1993, 58, 4139-4141.

22. Mihina, J.S.; Herbst, R.M. The reaction of nitriles with hydrazoic acid: Synthesis of monosubstituted tetrazoles. J. Org. Chem. 1950, 15, 1082-1092.

23. Kumar, A.; Narayanan, R.; Shechter, H. Rearrangement reactions of (hydroxyphenyl)carbenes. J. Org. Chem. 1996, 61, 4462-4465.

24. Huff, B.E.; Staszak, M.A. A new method for the preparation of tetrazoles from nitriles using trimethylsilylazide/trimethylaluminum. Tetrahedron Lett. 1993, 34, 8011-8014.

25. Fleming, A.; Gaire, J.; Kelleher, F.; McGinley, J.; McKee, V. Synthesis and characterisation of macrocycles containing both tetrazole and pyridine functionalities. Tetrahedron 2011, 67, 3260-3266.

26. Das, B.; Reddy, C.R.; Kumar, D.N.; Krishnaiah, M.; Narender, R. A simple, advantageous synthesis of 5-substituted $1 H$-tetrazoles. Synlett 2010, 3, 391-394.

27. Hu, T.P.; Liu, L.J.; Lv, X.L.; Chen, X.H.; He, H.Y.; Dai, F.N.; Zhang, G.Q.; Sun, D.F. Luminescent zinc and cadmium metal-organic frameworks based on tetrazole ligands. Polyhedron 2010, 13, 296-302.

28. Sureshbabu, V.V.; Venkataramanarao, R.; Naik, S.A.; Chennakrishnareddy, G. Synthesis of tetrazole analogues of amino acids using FMOC chemistry: isolation of amino free tetrazoles and their incorporation into peptides. Tetrahedron Lett. 2007, 48, 7038-7041.

29. Duncia, J.V.; Pierce, M.E.; Santella, J.B., III. Three synthetic routes to a sterically hindered tetrazole. A new one-step mild conversion of an amide into a tetrazole. J. Org. Chem. 1991, 56, 2395-2400.

30. Hill, J.; Ehrlich, J. Nucleophilic heteroaromatic substitution. II. Phthalazines. J. Org Chem. 1971, 36, 3248-3251.

31. Zheng, Y.; Bian, M.; Deng, X.Q.; Wang, S.B.; Quan, Z.S. Synthesis and anticonvulsant activity evaluation of 5-phenyl-[1,2,4]triazolo[4,3-c]quinazolin-3-amines. Arch. Pharm. (Weinheim). 2013, 346, 119-126.

32. Abu-Eittah, R.H.; Taha, F.; Hamed, M.M.; el-Kelany, Kh.E. Azido-tetrazole equilibrium in 2-azidothiazole system. Molecular orbital calculation. J. Mol. Struct. THEOCHEM 2009, 895, $142-147$.

33. Guan, L.P.; Sui, X.; Chang, Y.; Yan, Z.S.; Tong, G.Z.; Qu, Y.L. Design, synthesis and anticonvulsant activity evaluation of 7-substituted-[1,2,4]-triazolo[4,3-f]pyrimidine derivatives. Med. Chem. 2012, 8, 1076-1083.

34. Suaad, M.H.; Al-Majidi. Synthesis of some new 4-oxo-thiazolidines, tetrazole and triazole derived from 2-SH-benzothiazole and antimicrobial screening of some synthesized. J. Saudi Chem. Soc. 2014, 18, 893-901.

35. Mojzych, M.; Karczmarzyk, Z.; Wysocki, W.; Urbańczyk-Lipkowska, Z.; Żaczek, N. Valence tautomerism of new pyrazolo[4,3-e]tetrazole[4,5-b][1,2,4]triazines. J. Mol. Struct. 2014, 1067, 147-153.

36. Mojzych, M.; Karczmarzyk, Z.; Rykowski, A. Synthesis and structure of 7-methyl-5- phenyl-1Hpyrazolo[4,3-e]tetrazolo[4,5-b][1,2,4]triazine. J. Chem. Crystallogr. 2005, 35, 151-155. 
37. Aoyama, T.; Shioiri, T. New methods and reagents in organic synthesis. 31. Lithium trimethylsilyldiazomethane: A new synthon for the preparation of tetrazoles. Chem. Pharm. Bull. 1982, 30, 3450-3452.

38. Hassaneen, H.M.; Fahmi, A.A.; Abdelhamid, H.; Yassin, A.A.; Shawali, A.S. Synthesis of some triazole, tetrazole, and tetrazine derivatives from $N$ - $\beta$-naphthalenesulfonylbenzohydrazidoyl chlorides. J. Heterocycl. Chem. 1984, 21, 797-800.

39. Shawali, A.S.; Fahmi, A.A.; Eweiss, N.F. Azo coupling of benzenesulfonylhydrazones of heterocyclic aldehydes. J. Heterocycl. Chem. 1979, 16, 123-128.

40. Dave, C.G.; Shah, R.D. Annellation of triazole and tetrazole systems onto pyrrolo[2,3- $d$ ]pyrimidines: Synthesis of tetrazolo[1,5-c]-pyrrolo[3,2-e]-pyrimidines and triazolo[1,5-c]pyrrolo[3,2-e]pyrimidines as potential antibacterial agents. Molecules 2002, 7, 554-565.

41. Arulmurugan, S.; Kavitha, H.P. 2-Methyl-3-\{4-[2-(1H-tetrazol-5-yl)ethylamino]phenyl $\}-3 H-$ quinazolin-4-one. Molbank 2010, 2010, M695.

42. Dhayanithi, V.; Syed, S.S.; Kumaran, K.; Reguraman, K.; Sankar, J.; Ragavan, R.V.; Kumar Goud, P.S.; Kumari, N.S.; Pati, H.N. Synthesis of selected 5-thio-substituted tetrazole derivatives and evaluation of their antibacterial and antifungal activities. J. Serb. Chem. Soc. 2011, 76, 165-175.

43. Moustafa, M.A.; El-Sherbeny, M.A.; El-Sherbiny, D.T.; El-Sayed, S.M. Molecular modeling, synthesis and antimicrobial evaluation of new molecular hybrids of tetrazole derivatives. J. Am. Sci. 2012, 8, 973-986.

44. Jo, Y.W.; Im, W.B.; Rhee, J.K.; Shim, M.J.; Kim, W.B.; Choi, E.C. Synthesis and antibacterial activity of oxazolidinones containing pyridine substituted with heteroaromatic ring. Bioorg. Med. Chem. 2004, 12, 5909-5915.

45. Kanakaraju, S.; Sagar Vijay Kumar, P.; Prasanna, B.; Chandramouli, G.V. Design, synthesis, and in vitro antimicrobial evaluation of fused pyrano[3,2-e]tetrazolo[1,5-c]pyrimidines and diazepines. ISRN Org. Chem. 2013, 21, 635384-635393.

46. Peesapati, V.; Venkata, S.C. ChemInform abstract: synthesis and antimicrobial activity of new triazolo/tetrazolo-pyridazine [6,7] benzocycloheptenes. Indian J. Chem. 2002, 41, 839-844.

47. Mohite, P.B.; Bhaskar, V.H. Synthesis, characterization and study of in vitro antimicrobial activity of some substituted $N^{\prime}$-[arylidene]-2-(5-phenyl-1H-tetrazol-1-yl) acetohydrazide. Iran. J. Pharm. Sci. 2010, 6, 179-184.

48. Antypenko, L.M.; Kovalenko, S.I.; Antypenko, O.M.; Katsev, A.M.; Achkasova, O.M. Design and evaluation of novel antimicrobial and anticancer agents among tetrazolo[1,5-c]-quinazoline5-thione S-derivatives. Sci. Pharm. 2013, 81, 15-42.

49. Ramiz, M.M.M.; Abdel-Rahman, A.A.H. Antimicrobial activity of newly synthesized 2,5-disubstituted 1,3,4-thiadiaozle derivatives. Bull. Korean Chem. Soc. 2011, 32, 4227-4232.

50. El-Sayed, W.A.; Ali, O.M.; Zyada, R.A.; Mohamed, A.A.; Abdel-Rahman, A.A. Synthesis and antimicrobial activity of new substituted thienopyrimidines, their tetrazolyl and sugar derivatives. Acta Pol. Pharm. 2012, 69, 439-447.

51. Upadhayaya, R.S.; Jain, S.; Sinha, N.; Kishore, N.; Chandra, R.; Arora, S.K. Synthesis of novel substituted tetrazoles having antifungal activity. Eur. J. Med. Chem. 2004, 39, 579-592. 
52. Matysiak, J.; Niewiadomy, A.; Krajewska-Kułak, E.; Macik-Niewiadomy, G. Synthesis of some 1-(2,4-dihydroxythiobenzoyl)imidazoles, -imidazolines and -tetrazoles and their potent activity against Candida species. Farmaco 2003, 58, 55-61.

53. Mohite, P.B.; Bhaskar, V.H. In vitro evaluation of tetrazoles as a novel class of anti-Mycobacterium tuberculosis agents. Adv. Pharm. Bull. 2012, 2, 31-36.

54. Malik, M.A.; al-Thabaiti, S.A.; Malik, M.A. Synthesis, structure optimization and antifungal screening of novel tetrazole ring bearing acyl-hydrazones. Int. J. Mol. Sci. 2012, 13, 10880-10898.

55. El-Sayed, W.A.; Abdel Megeid, R.E.; Abbas, H.A. Synthesis and antimicrobial activity of new 1-[(tetrazol-5-yl)methyl]indole derivatives, their 1,2,4-triazole thioglycosides and acyclic analogs. Arch. Pharm. Res. 2011, 34, 1085-1096.

56. Kategaonkar, A.H.; Pokalwar, R.U.; Sonar, S.S.; Gawali, V.U.; Shingate, B.B.; Shingare, M.S. Synthesis, in vitro antibacterial and antifungal evaluations of new $\alpha$-hydroxyphosphonate and new $\alpha$-acetoxyphosphonate derivatives of tetrazolo[1,5-a]quinoline. Eur. J. Med. Chem. 2010, $45,1128-1132$.

57. Dekhane, D.V.; Pawar, S.S.; Gupta, S.; Shingare, M.S.; Patil, C.R.; Thore, S.N. Synthesis and anti-inflammatory activity of some new 4,5-dihydro-1,5-diaryl-1H-pyrazole-3-substitutedheteroazole derivatives. Bioorg. Med. Chem. Lett. 2011, 21, 6527-6532.

58. Maria Dorathi Anu, M.; Jayanthi, M.; Damodar Kumar, S.; Raja, S.; Thirunavukkarasu, S.V. Synthesis, characterization, antibacterial \& anti-inflammatory effects of substituted tetrazole derivatives based on different types of carbazone and benzaldehyde. Int. J. ChemTech Res. 2013, 5, 1982-1990.

59. Bekhit, A.A.; el-Sayed, O.A.; Aboulmagd, E.; Park, J.Y. Tetrazolo[1,5- $a$ ]quinoline as a potential promising new scaffold for the synthesis of novel anti-inflammatory and antibacterial agents. Eur. J. Med. Chem. 2004, 39, 249-255.

60. Al-Hourani, B.J.; Sharma, S.K.; Mane, J.Y.; Tuszynski, J.; Baracos, V.; Kniess, T.; Suresh, M.; Pietzsch, J.; Wuest, F. Synthesis and evaluation of 1,5-diaryl-substituted tetrazoles as novel selective cyclooxygenase-2 (COX-2) inhibitors. Bioorg. Med. Chem. Lett. 2011, 21, 1823-1826.

61. Navidpour, L.; Amini, M.; Shafaroodi, H.; Abdi, K.; Ghahremani, M.H.; Dehpour, A.R.; Shafiee, A. Design and synthesis of new water-soluble tetrazolide derivatives of celecoxib and rofecoxib as selective cyclooxygenase-2 (COX-2) inhibitors. Bioorg. Med. Chem. Lett. 2006, 16, 4483-4487.

62. Kuduk, S.D.; Chang, R.K.; Dipardo, R.M.; di Marco, C.N.; Murphy, K.L.; Ransom, R.W.; Reiss, D.R.; Tang, C.; Prueksaritanont, T.; Pettibone, D.J.; et al. Bradykinin B1 receptor antagonists: An $\alpha$-hydroxy amide with an improved metabolism profile. Bioorg. Med. Chem. Lett. 2008, 18, 5107-5110.

63. Bhaskar, V.H.; Mohite, P.B. Design, synthesis, characterization and biological evaluation of some novel 1,5-disubstituted tetrazole as potential anti-inflammatory agents. J. Optoelectron. Biomed. Meter. 2010, 2, 231-237.

64. Volonté, C.; Apolloni, S.; Skaper, S.D.; Burnstock, G. P2X7 receptors: Channels, pores and more. CNS Neurol. Disord. Drug Targets 2012, 11, 705-721.

65. Rajasekaran, A.; Thampi, P.P. Synthesis and analgesic evaluation of some 5-[ $\beta-(10-$ phenothiazinyl)ethyl]-1-(acyl)-1,2,3,4-tetrazoles. Eur. J. Med. Chem. 2004, 39, 273-279. 
66. Gajanan Khanage, S.; Raju, A.; Baban Mohite, P.; Bhanudas Pandhare, R. Analgesic activity of some 1,2,4-triazole heterocycles clubbed with pyrazole, tetrazole, isoxazole and pyrimidine. Adv. Pharm. Bull. 2013, 3, 13-18.

67. Rajasekaran, A.; Thampi, P.P. Synthesis and antinociceptive activity of some substituted- $\{5-[2-$ (1,2,3,4-tetrahydrocarbazol-9-yl)ethyl]tetrazol-1-yl\}alkanones. Eur. J. Med. Chem. 2005, 40, 1359-1364.

68. Kumar, C.N.S.S.P.; Parida, D.K.; Santhoshi, A.; Kota, A.K.; Sridhar, B.; Rao, V.J. Synthesis and biological evaluation of tetrazole containing compounds as possible anticancer agents. Med. Chem. Commun. 2011, 2, 486-492.

69. El-Sayed, W.A.; El-Kosy, S.M.; Ali, O.M.; Emselm, H.M.; Abdel-Rahman, A.A. Anticancer activity of new (tetrazol-5-yl) methylindole derivatives and their acyclic c-nucleoside analogs. Acta Pol. Pharm. 2012, 69, 669-677.

70. Romagnoli, R.; Baraldi, P.G.; Salvador, M.K.; Preti, D.; Tabrizi, M.A.; Brancale, A.; Fu, X.H.; Li, J.; Zhang, S.Z.; Hamel, E.; et al. Synthesis and evaluation of 1,5-disubstituted tetrazoles as rigid analogues of combretastatin A-4 with potent antiproliferative and antitumor activity. J. Med. Chem. 2011, 55, 475-488.

71. Kádár, Z.; Kovács, D.; Frank, É.; Schneider, G.; Huber, J.; Zupkó, I.; Bartók, T.; Wölfling, J. Synthesis and in vitro antiproliferative activity of novel androst-5-ene triazolyl and tetrazolyl derivatives. Molecules 2011, 16, 4786-4806.

72. Al-Duaij, O.K.; Hafez, H.N.; el-Gazzar, A.R.B.A. Synthesis of novel series of benzothieno [2,3- $d$ ] pyrimidine derivatives, promising anticancer agents. J. Chem. Chem. Eng. 2013, 7, 725-742.

73. Jackman, A.L.; Kimbell, R.; Aherne, G.W.; Brunton L.; Jansen, G.; Stephens, T.C.; Smith, M.N.; Wardleworth, J.M.; Boyle, F.T. Cellular pharmacology and in vivo activity of a new anticancer agent, ZD9331: A water-soluble, nonpolyglutamatable, quinazoline-based inhibitor of thymidylate synthase. Clin. Cancer Res. 1997, 3, 911-921.

74. Arshad, M.; Bhat, A.R.; Pokharel, S.; Kim, J.E.; Lee, E.J.; Athar, F.; Choi, I. Synthesis, characterization and anticancer screening of some novel piperonyl-tetrazole derivatives. Eur. J. Med. Chem. 2014, 71, 229-236.

75. Jedhe, G.S.; Paul, D.; Gonnade, R.G.; Santra, M.K.; Hamel, E.; Nguyen, T.L.; Sanjayan, G.J. Correlation of hydrogen-bonding propensity and anticancer profile of tetrazole-tethered combretastatin analogues. Bioorg. Med. Chem. Lett. 2013, 23, 4680-4684.

76. Mahboob, A.; Shahab, A.A.N.; Ahmad, H.; Dong-Ung, L.; Soonheum, P. Synthesis, characterization, X-ray diffraction, antimicrobial and in vitro cytotoxicity studies of 7 $\alpha$-Aza-B-homostigmast-5-eno[7a,7-d]tetrazole. Comptes Rendus Chimie 2013, 16, 201-206.

77. Yuan, H.; Silverman, R.B. Structural modifications of (1S,3S)-3-amino-4-difluoromethylenecyclopentanecarboxylic acid, a potent irreversible inhibitor of GABA aminotransferase. Bioorg. Med. Chem. Lett. 2007, 17, 1651-1654.

78. Rostom, S.A.; Ashour, H.M.; El Razik, H.A.; Abd El Fattah, H.; El-Din, N.N. Azole antimicrobial pharmacophore-based tetrazoles: Synthesis and biological evaluation as potential antimicrobial and anticonvulsant agents. Bioorg. Med. Chem. 2009, 17, 2410-2422. 
79. Wang, S.B.; Deng, X.Q.; Zheng, Y.; Yuan, Y.P.; Quan, Z.S.; Guan, L.P. Synthesis and evaluation of anticonvulsant and antidepressant activities of 5-alkoxytetrazolo[1,5-c]thieno[2,3-e]pyrimidine derivatives. Eur. J. Med. Chem. 2012, 56, 139-144.

80. Sun, X.Y.; Wei, C.X.; Deng, X.Q.; Sun, Z.G.; Quan, Z.S. Synthesis and primary anticonvulsant activity evaluation of 6-alkyoxyl-tetrazolo [5,1-a]phthalazine derivatives. Arzneimittelforschung 2010, 60, 289-292.

81. Wu, J.; Wang, Q.; Guo, J.; Hu, Z.; Yin, Z.; Xu, J.; Wu, X. Characterization of angiotensin II antagonism displayed by $\mathrm{Ib}$, a novel nonpeptide angiotensin AT(1) receptor antagonist. Eur. J. Pharmacol. 2008, 589, 220-224.

82. Yan, B.; Wang, G.; Sun, J.; Li, X.; Zheng, Y.; Ai, H.; Lv, H.; Wu, X.; Xu, J. Identification of the major metabolites of 5-n-butyl-4-\{4-[2-(1H-tetrazole-5-yl)-1H-pyrrol-1-yl]phenylmethyl $\}-2,4-$ dihydro-2-(2,6-dichloridephenyl)-3H-1,2,4-triazol-3-one, a new angiotensin type 1 receptor antagonist, in rat bile by HPLC-diode array detection-MS and HPLC-MS/MS. Biomed. Chromatogr. 2007, 21, 912-924.

83. Kim, J.H.; Lee, J.H.; Paik, S.H.; Kim, J.H.; Chi, Y.H. Fimasartan, a novel angiotensin II receptor antagonist. Arch. Pharm. Res. 2012, 35, 1123-1126.

84. Choi, M.J.; Kwon, G.H.; Han, N.S.; Yoo, B.W.; Kim, J.H.; Paik, S.H.; Chi, Y.H.; Lee, K.T.; Lee, J.Y. Development of 3D-QSAR CoMSIA models for 5-(biphenyl-2-yl)-1H-tetrazole derivatives as angiotensin II receptor type 1 (AT1) antagonists. Bioorg. Med. Chem. Lett. 2013, $23,4540-4546$.

85. Arhancet, G.B.; Woodard, S.S.; Iyanar, K.; Case, B.L.; Woerndle, R.; Dietz, J.D.; Garland, D.J.; Collins, J.T.; Payne, M.A.; Blinn, J.R.; et al. Discovery of novel cyanodihydropyridines as potent mineralocorticoid receptor antagonists. J. Med. Chem. 2010, 53, 5970-5978.

86. Gao, Y.L.; Zhao, G.L.; Liu, W.; Shao, H.; Wang, Y.L.; Xu, W.R.; Tang, L.D.; Wang, J.W. Design, synthesis and in vivo hypoglycemic activity of tetrazole-bearing $N$-glycosides as SGLT2 inhibitors. Indian J. Chem. B. 2010, 49, 1499-1508.

87. Momose, Y.; Maekawa, T.; Odaka, H.; Ikeda, H.; Sohda, T. Novel 5-substituted-1H-tetrazole derivatives as potent glucose and lipid lowering agents. Chem. Pharm. Bull (Tokyo) 2002, 50, $100-111$.

88. Pegklidou, K.; Koukoulitsa, C.; Nicolaou, I.; Demopoulos, V.J. Design and synthesis of novel series of pyrrole based chemotypes and their evaluation as selective aldose reductase inhibitors. A case of bioisosterism between a carboxylic acid moiety and that of a tetrazole. Bioorg. Med. Chem. 2010, 18, 2107-2114.

89. Wani, M.Y.; Bhat, A.R.; Azam, A.; Choi, I.; Athar, F. Probing the antiamoebic and cytotoxicity potency of novel tetrazole and triazine derivatives. Eur. J. Med. Chem. 2012, 48, 313-320.

90. Wani, M.Y.; Bhat, A.R.; Azam, A.; Lee, D.H.; Choi, I.; Athar, F. Synthesis and in vitro evaluation of novel tetrazole embedded 1,3,5-trisubstituted pyrazoline derivatives as Entamoeba histolytica growth inhibitors. Eur. J. Med. Chem. 2012, 54, 845-854.

91. Faria, J.V.; dos Santos, M.S.; Bernardino, A.M.; Becker, K.M.; Machado, G.M.; Rodrigues, R.F.; Canto-Cavalheiro, M.M.; Leon, L.L. Synthesis and activity of novel tetrazole compounds and their pyrazole-4-carbonitrile precursors against Leishmania spp. Bioorg. Med. Chem. Lett. 2013, 23, 6310-6312. 
92. Hutchinson, D.W.; Naylor, M. The antiviral activity of tetrazole phosphonic acids and their analogues. Nucl. Acids Res. 1985, 13, 8519-8530.

93. Wang, S.X.; Fang, Z.; Fan, Z.J.; Wang, D.; Li, Y.D.; Ji, X.T.; Hua, X.W.; Huang Y.; Kalinina, T.A.; Bakulev, V.A.; et al. Synthesis of tetrazole containing 1,2,3- hiadiazole derivatives via U-4CR and their anti-TMV activity. Chin. Chem. Lett. 2013, 24, 889-892.

94. Yeung, K.S.; Qiu, Z.; Yin, Z.; Trehan, A.; Fang, H.; Pearce, B.; Yang, Z.; Zadjura, L.; D'Arienzo, C.J.; Riccardi, K.; et al. Inhibitors of HIV-1 attachment. Part 8: the effect of C7-heteroaryl substitution on the potency, and in vitro and in vivo profiles of indole-based inhibitors. Bioorg. Med. Chem. Lett. 2013, 23, 203-208.

95. Yeung, K.S.; Qiu, Z.; Yang, Z.; Zadjura, L.; D’Arienzo, C.J.; Browning, M.R.; Hansel, S.; Huang, X.S.; Eggers, B.J.; Riccardi, K.; et al. Inhibitors of HIV-1 attachment. Part 9: An assessment of oral prodrug approaches to improve the plasma exposure of a tetrazole-containing derivative. Bioorg. Med. Chem. Lett. 2013, 23, 209-212.

96. Karabanovich, G.; Roh, J.; Smutný, T.; Němeček, J.; Vicherek, P.; Stolaříková, J.; Vejsová, M.; Dufková, I.; Vávrová, K.; Pávek, P.; et al. 1-Substituted-5-[(3,5-dinitrobenzyl)sulfanyl]-1 $H$-tetrazoles and their isosteric analogs: A new class of selective antitubercular agents active against drug-susceptible and multidrug-resistant mycobacteria. Eur. J. Med. Chem. 2014, 82, 324-340.

97. Kikuchi, T.; Ito, N.; Suzuki, M.; Kusai, A.; Iseki, K.; Sasaki, H. Self-association properties of 4-[1-hydroxy-1-methylethyl]-2-propyl-1-[4-[2-[tetrazole-5-yl]phenyl]phenyl]methylimidazole-5carboxylic acid monohydrate (CS-088), an antiglaucoma ophthalmic agent. Int. J. Pharm. 2005, 299, 100-106.

98. Adibi, H.; Rashidi, A.; Khodaei, M.M.; Alizadeh, A.; Majnooni, M.B.; Pakravan, N.; Abiri, R.; Nematollahi, D. Catecholthioether derivatives: preliminary study of in vitro antimicrobial and antioxidant activities. Chem. Pharm. Bull. (Tokyo) 2011, 59, 1149-1152.

99. Singh, U.S.; Shankar, R.; Yadav, G.P.; Kharkwal, G.; Dwivedi, A.; Keshri, G.; Singh, M.M.; Moulik, P.R.; Hajela, K. Synthesis and structure guided evaluation of estrogen agonist and antagonist activities of some new tetrazolyl indole derivatives. Eur. J. Med. Chem. 2008, 43, 2149-2158.

100. Li, J.J.; Wang, H.; Li, J.; Qu, F.; Swartz, S.G.; Hernández, A.S.; Biller, S.A.; Robl, J.A.; Tino, J.A.; Slusarchyk, D.; et al. Tetrazole based amides as growth hormone secretagogues. Bioorg. Med. Chem. Lett. 2008, 18, 2536-2539.

(C) 2015 by the authors; licensee MDPI, Basel, Switzerland. This article is an open access article distributed under the terms and conditions of the Creative Commons Attribution license (http://creativecommons.org/licenses/by/4.0/). 